


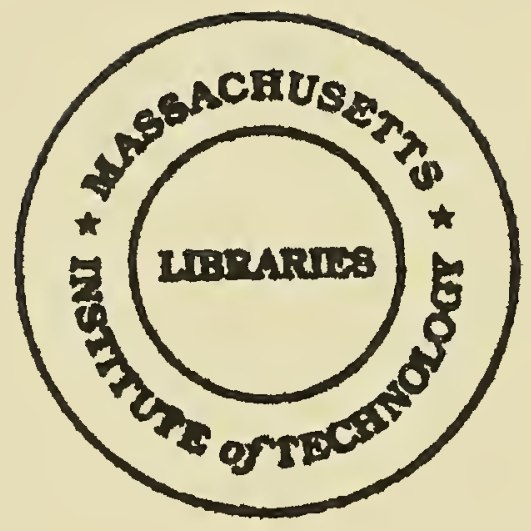





\section{Digitized by the Internet Archive in 2011 with funding from Boston Library Consortium Member Libraries}


Massachusetts Institute of Technology

Department of Economics

Working Paper Series

\title{
Why Was Stock Market Volatility So High \\ During the Great Depression? Evidence from 10 Countries during the Interwar Period
}

\author{
Hans-Joachim Voth
}

Working Paper 02-09

February 2002

\author{
Room E52-251 \\ 50 Memorial Drive \\ Cambridge, MA 02142
}

This paper can be downloaded without charge from the Social Science Research Network Paper Collection at http://papers.ssrn.com/paper.taf?abstract_id=x xxxx 


\title{
Massachusetts Institute of Technology Department of Economics Working Paper Series
}

\section{Why Was Stock Market Volatility So High During the Great Depression? Evidence from 10 Countries during the Interwar Period}

Hans-Joachim Voth

Working Paper 02-09

February 2002

\author{
Room E52-251 \\ 50 Memorial Drive \\ Cambridge, MA 02142
}

This paper can be downloaded without charge from the Social Science Research Network Paper Collection at http://papers.ssrn.com/paper.taf?abstract_id=xxxxx 
MASSACHUSETIS INSTITUTE OF TECHNOLDGY

MAR 152002

LIBRARIES 


\title{
Why Was Stock Market Volatility So High During the Great Depression? \\ Evidence from 10 Countries during the Interwar Period
}

\author{
Hans-Joachim Voth \\ Economics Department, MIT \\ es \\ Departament d'Economia, UPF
}

12.2 .2002

\begin{abstract}
:
The extreme levels of stock price volatility found during the Great Depression have often been attributed to political uncertainty. This paper performs an explicit test of the Merton/Schwert hypothesis that doubts about the survival of the capitalist system were partly responsible. It does so by using a panel data set on political unrest, demonstrations and other indicators of instability in a set of 10 developed countries during the interwar period. Fear of worker militancy and a possible revolution can explain a substantial part of the increase in stock market volatility during the Great Depression.
\end{abstract}

JEL: $\quad$ G12, G14, G18, E66, N22, N24, N12, N14

Keywords: Stock price volatility, political uncertainty, worker militancy, Great Depression. 

During the Great Depression, aggregate stock market volatility in a large number of advanced economies reached levels not seen before or since. Schwert (1989b) estimates that in the US, there was a two- to threefold increase in variability. According to his measure, the monthly variation of stock returns peaked at over 20 percent in 1932. Other developed countries experienced similar increases in volatility. This is all the more puzzling since macroeconomic series such as money growth and interest rates, showed markedly smaller increases in variability (Schwert 1989b). As a general rule, neither wars nor periods of financial panic appear to lead to significantly higher variability of equity returns over an extended period - despite the highly unstable behavior of other macroeconomic series. Recessions, however, are clearly associated with higher volatility (Schwert 1989a). Stock returns and their volatility in general show only a tenuous link with fundamentals (Cutler, Poterba and Summers 1989), even if uncertainty about these fundamentals can in part explain variability (David and Veronesi 2001).

Why was stock market volatility in the US so much higher during the Great Depression than at any time before or since? In his seminal paper, Schwert (1989) concludes that there is a "volatility puzzle". Because all other likely explanations are insufficient, the most likely one is that the very survival of the capitalist system, even in the United States, was seen to be at risk. As Robert Merton has pointed out, the Russian Revolution occurred little more than a decade earlier. In the case of a communist take-over, for example, private ownership of the means of production would have come to an end. Even relatively small changes in the probability of a momentous shock like this might lead to extreme swings in market sentiment occurred. This suggests that examinations of stock volatility may be affected by a particular form of the "Peso problem". Some economists observing extreme swings in stock prices ex post have conclude that there is no rational explanation for them (Schiller 1981). ${ }^{1}$ If possible regime switches that ultimately failed to materialize were partly responsible, this would be erroneous Schwert 1989b). ${ }^{2}$ As Schwert (1989b, 1146) argued: "With the benefit of hindsight, we know that the U.S. and world economies came out of the Depression quite well. At the time, however, investors could not have had such confident expectations." The argument that political risk during the Great Depression is partly to blame is supported by the recent finding that unusually high levels of synchronicity of individual stock returns contributed substantially to aggregate volatility (Morck, Yeung and Yu 2000). ${ }^{3}$

1 Cf. the critique in Kleidon 1986.

2 Note that this is similar to the standard problem in bubble tests. Cf. Hamilton and Whiteman 1985, Hamilton 1986.

3 They also demonstrate that lower synchronicity is systematically associated with "better government" (defined as a composite measure of the risk of expropriation, government corruption, and the risk of the government repudiating contracts). 
This paper adopts a simple strategy to test the Schwert/Merton hypothesis empirically. We use a data set on political risk and stock price variability in a group of 10 countries during the interwar period, 1919-1939. If fear of a collapse of capitalism was to blame for the extreme stock volatility in the US, countries facing a higher probability of communist takeover or other severe disruptions of the civic and legal order should have experienced particularly large equity return volatility. Our data set, which contains a number of relatively advanced.countries from Europe (Germany, France, Sweden, Italy, UK, Netherlands, Belgium, Norway, and Switzerland) plus the US is useful in testing this proposition. While some of these nations - such as Germany, France, and the UK - went through extreme social upheavals and political turmoil, others such as Switzerland were largely unaffected. If the volatility of stock markets increased in response to mounting challenges to the capitalist order, we should find systematic associations in our panel both in the cross-sections and within each country over time. In view of the recent literature on the political economy of democratization, the $1920 \mathrm{~s}$ and $1930 \mathrm{~s}$ are also a particularly useful period to study. Acemoglu and Robinson argue that, over the last 200 years, extending the franchise has effectively been a way for capital owners to commit credibly to future redistribution (Acemoglu and Robinson 1999, 2000). If this is true, then any challenges by disaffected workers should be much more threatening once universal suffrage has been granted, and the 'ruling classes' have run out of 'franchise cards' to play. Since most countries had more or less completed the process of giving the vote to the lower classes by the end of World War II, credible promises of future redistribution became increasingly hard to make within the existing political and social order.

The exercise is similar in spirit to recent work on interwar Germany (Bittlingmayer 1998) and on emerging markets (Bekaert and Harvey 1997, Mei 1999). Bittlingmayer argues that the extreme levels of volatility in Germany during the early 1920s are driven by exogenous political events, such as the revolution of $1918 / 19$, the Hitler putsch in Munich, and the French invasion of the Ruhr. Bekaert and Harvey show that country credit ratings based on surveys of business men are weakly associated with stock market volatility, and Mei argues that stock prices become less stable during elections. While Bittlingmayer presents no systematic test of the connection between political instability and stock return variability, Bekaert and Harvey only find a small effect from political risk. Also, their variable is - as they admit - a composite measure of political and macroeconomic uncertainty (Bekaert and Harvey 1997).

There is a voluminous literature on the determinants of revolutions and their relation to demographic, economic and social conditions, with contributions from sociologists and economists DeFronzo 1991; Goldstone 1991; Goldstone and Merton 1986; Grossman 1999). While the interactions are far more complicated than a simple immiserization model would predict - 
with economic distress leading to revolutionary bids for power - inequality and instability appear reliably associated (Alesina and Perotti 1996, Muller and Seligson 1987). There is also some indication that revolutions are significantly more likely during recessions, when opportunity costs are relatively low (Acemoglu and Robinson 1999, 2000; Gasiorowski 1995; Prezworski et al. 1996). There are therefore strong reasons to believe that the Great Depression should have been a good period for revolutionaries, and that this realization concerned contemporaries. The slump was protracted and led to unprecedented levels of unemployment. In countries where the 1920 s had seen great increases in prosperity, inequality had reached extreme levels (Galbraith 1962).

Our panel data set does not contain information on the threat of communist takeover and revolution itself. Instead, we use a number of variables that could reasonably be expected to help contemporaries gauge the strength of workers militancy and the dangers to the established economic and legal system. These include the number of general strikes, of riots and anti-government demonstrations, of violent attempts to overthrow the established order, as well as indicators of the stability of governments.

I find that these political indicators can help to explain the history of stock market volatility in the interwar period. After controlling for macroeconomic sources of variability, many - but by no means all indicators of worker militancy and left-wing radicalism led to significant and large swings in the value of equities. Also, crack-downs on the opposition and purges clearly helped to stabilize expectations, leading to lower volatility. Periods of unstable government also appear to be weakly associated with greater volatility.

\section{Data}

The stock indices in this study are similar to the set employed by Jorion and Goetzmann (1999), and made available through Global Financial Data. ${ }^{4}$ They are all broad market indices, relative to the size of the domestic equity market that they represent. In most cases GFD has attempted to reconstruct the equivalent of commonly used indices such as the S\&P-500 for more distant periods in the past (details in the data appendix). All series were deflated by the consumer price index. Despite these broad similarities, some differences should be noted. The number of shares varies considerably - the Norwegian stock index is modeled on the OBX-25, containing the 25 largest stocks by market capitalization, whereas the British and Dutch series represent all-share indices. Differences in the composition of indices (and the relative concentration of capitalizations) can have considerable influence on aggregate measures of volatility (Bekaert and Harvey 1997). In the empirical

\footnotetext{
4 The Jorion and Goetzmann dataset is not publicly available.
} 
part of the paper, we will try to adjust for this by using fixed-effect regressions.

Average share prices could swing wildly - in June 1923, the German index gained 61 percent, only to lose 52 percent in August. By far the highest level of average volatility is recorded for Germany, which during the years 1919-39 shows a yearly standard deviation of monthly of 10.3 percent. Belgium and the US are markedly more stable, with average volatility of 7 percent. At the opposite end of the spectrum, the UK and Norway recorded standard deviations of only 3.1 and 2.6 percent.

All the countries in our sample show higher than average levels of volatility during the Great Depression, with one notable exception. Germany saw the highest standard deviation of monthly returns during 1923, when the hyperinflation reached fever pitch, the French invaded the Ruhr, and the country was fighting for its survival as a nation state (Feldman 1993). 1931/1932 are by far the most common years for maximum variability of share prices - eight out of our ten countries see the peak in equity volatility in one of these two years. Maximum volatility was again highest in Germany, both in absolute terms and relative to the average for the country during the period 1919-1938 as a whole. In 1923, the standard deviation was more than four times higher than normal, reaching 43.5 percent. In absolute terms, the US, Sweden and Belgium recorded relatively high levels of variability. Relative to average share price volatility, a broadly similar ranking emerges. In six out of ten countries, the standard deviation more than doubled, led by Germany, Sweden, the US and the UK. In Belgium, on the other hand, volatility in 1931 rose by only half. Table I also presents the statistics on skewness and kurtosis. Jarque-Bera tests (not reported) demonstrate that, in each case, the null of normality can be rejected. 
Table I

Real stock returns in 10 countries, 1919-1938

Continuously compounded monthly returns and measures of volatility, based on monthly returns. The standard deviation is calculated on the basis of monthly returns for each year. For details of the data, cf. the Data Appendix.

\begin{tabular}{|c|c|c|c|c|c|c|c|c|c|}
\hline & $\begin{array}{c}\text { average } \\
\text { volatility }\end{array}$ & $\begin{array}{c}\text { largest } \\
\text { monthly } \\
\text { gain }\end{array}$ & $\begin{array}{c}\text { largest } \\
\text { monthly } \\
\text { loss }\end{array}$ & $\begin{array}{l}\text { average } \\
\text { annual } \\
\text { return }\end{array}$ & $\begin{array}{c}\text { highest } \\
\text { volatility }\end{array}$ & $\begin{array}{c}\text { year of } \\
\text { highest } \\
\text { volatility }\end{array}$ & $\begin{array}{c}\text { ratio } \\
\text { max/ } \\
\text { average } \\
\end{array}$ & $\begin{array}{c}\text { skew- } \\
\text { ness }\end{array}$ & $\begin{array}{l}\text { kur } \\
\text { tosis }\end{array}$ \\
\hline Germany & 0.103 & 0.61 & -0.52 & 0.055 & 0.435 & 1923 & 4.22 & 0.07 & 4.92 \\
\hline UK & 0.031 & 0.11 & -0.11 & 0.018 & 0.064 & 1931 & 2.08 & -0.46 & 1.39 \\
\hline Belgium & 0.070 & 0.27 & -0.17 & -0.064 & 0.105 & 1931 & 1.50 & 0.59 & 1.08 \\
\hline USA & 0.071 & 0.35 & .0 .35 & 0.037 & 0.182 & 1932 & 2.58 & -0.13 & 4.54 \\
\hline France & 0.057 & 0.20 & -0.18 & -0.027 & 0.095 & 1936 & 1.67 & 0.21 & 0.62 \\
\hline Italy & 0.050 & 0.24 & -0.21 & -0.047 & 0.099 & 1932 & 1.98 & 0.30 & 2.96 \\
\hline $\begin{array}{l}\text { Nether- } \\
\text { lands }\end{array}$ & 0.044 & 0.23 & -0.15 & -0.025 & 0.085 & 1932 & 1.94 & -0.02 & 2.32 \\
\hline Sweden & 0.046 & 0.18 & .0 .39 & 0.016 & 0.148 & 1932 & 3.22 & -1.20 & 9.75 \\
\hline Norway & 0.026 & 0.10 & -0.09 & 0.010 & 0.053 & 1932 & 2.06 & -0.22 & 1.13 \\
\hline $\begin{array}{l}\text { Switzer- } \\
\text { land }\end{array}$ & 0.041 & 0.27 & -0.23 & 0.048 & 0.088 & 1931 & 2.16 & -0.12 & 6.97 \\
\hline
\end{tabular}

The data on civic unrest and political stability is from the cross-national data set compiled by Arthur Banks under the auspices of the Center for Comparative Political Research at the State University of New York. In addition to a set of demographic and economic variables, it also contains information on the nature of the political system and social instability for a set of 166 over the period 1815-1973. Table II compares the main indicators for our subsample of ten countries, and the data set as a whole. Overall, the interwar data set for a number of countries that are developed today shows a relatively high level of political instability and violence. For most indicators of political uncertainty, the levels are twice the average observed in the larger data set. This is true of the number of assassinations, of general strikes, government crises, riots, and anti-government demonstrations. In three categories, the subsample actually appears more stable - there were fewer revolutions, purges and acts of guerrilla warfare than in the 166 country sample. The variability of our measures of political instability is considerable, ranging from a coefficient of variation of 3.9 in the case of revolutions to 1.98 for government crises. While Germany scores very high on almost all measures of political fragility, recording a total of 188 events of unrest, Switzerland marks the opposite extreme. Only three acts indicating instability are recorded - two assassinations (in 1919 and 1923) and one riot (in 1932). 


\section{Table II}

\section{Measures of Political Instability}

The data is from Banks 1976, and shows the number of events per country and year. All data is for the years 1919-1939, where available. The countries are Belgium, Switzerland, France, Germany, Italy, Netherlands, Norway, Sweden, UK and US. The last column gives the ratio of the average number of events in the 10 country sample divided by the average number of events in the 166 nation sample.

\begin{tabular}{|c|c|c|c|c|c|c|c|c|c|}
\hline \multirow{4}{*}{$\begin{array}{l}\text { number of } \\
\text { assassinations } \\
\text { general strikes }\end{array}$} & \multicolumn{4}{|c|}{$\begin{array}{l}10 \text { Country Interwar } \\
\text { Sample }\end{array}$} & \multicolumn{4}{|c|}{$\begin{array}{l}166 \text { Nation } \\
\text { Sample }\end{array}$} & \multirow[b]{2}{*}{$\begin{array}{c}\text { ratio } \\
\text { averages }\end{array}$} \\
\hline & average & st.dev. & $\max$ & $\mathrm{N}$ & average & st.dev. & $\max$ & $\mathrm{N}$ & \\
\hline & 0.28 & 0.77 & 5 & 233 & 0.14 & 0.51 & 9 & 4066 & 2.01 \\
\hline & 0.26 & 0.62 & 3 & 233 & 0.11 & 0.51 & 13 & 4066 & 2.37 \\
\hline guerrilla warfare & 0.22 & 0.81 & 7 & 233 & 0.28 & 1.09 & 34 & 4066 & 0.79 \\
\hline $\begin{array}{l}\text { government } \\
\text { crises }\end{array}$ & 0.60 & 1.19 & 6 & 233 & 0.30 & 0.73 & 7 & 4066 & 2.00 \\
\hline purges & 0.27 & 0.75 & 4 & 233 & 0.34 & 1.01 & 34 & 4066 & 0.78 \\
\hline riots & 1.47 & 2.99 & 22 & 233 & 0.64 & 2.18 & 55 & 4066 & 2.29 \\
\hline revolutions & 0.07 & 0.27 & 2 & 233 & 0.20 & 0.56 & 6 & 4066 & 0.34 \\
\hline $\begin{array}{l}\text { anti-government } \\
\text { demonstrations }\end{array}$ & 0.75 & 1.62 & 11 & 233 & 0.35 & 1.69 & 60 & 4066 & 2.14 \\
\hline
\end{tabular}

There is also plenty of change over time. While 1919 saw, for example, four times the average number of assassinations in the subsample of 10 countries, there were none in 1936-38. The number of anti-government demonstrations reached more than twice is average level in 1932, and the number of riots peaked in 1934 at almost twice its normal frequency. Unsurprisingly, the tendency of governments to resort to violent acts of repression also peaked during the tumultuous years of the Great Depression, with the frequency of purges reaching a high of 2.6 times its average level in 1934.

\section{Political Instability and Civic Unrest during the Interwar Period}

Europe and the US experienced two waves of turmoil and increasing uncertainty. In each case, the continued existence of the established political and economic order was in question. Following the end of World War I and the Russian Revolution in 1917, chaos and civic unrest broke out in numerous countries. After the end of the Habsburg dynasty and the disintegration of the Austro-Hungarian Empire, a large number of new nation states was formed. In Germany, the Emperor abdicated; revolution came when Navy sailors mutinied and widespread strikes broke out. Returning troops supporting the Social Democratic government were fighting former comrades who sought to establish a German equivalent to the Soviet Union, led by two leading communist intellectuals of the day, Rosa Luxembourg and Karl Liebknecht (Winkler 1985). Right-wing putsches such 
as the Kapp Putsch in 1920 and the Hitler Putsch in 1923 destabilized the new democratic order, already undermined by the harsh terms of the Versailles treaty. Leading political figures such as Matthias Erzberger and Walter Rathenau fell victim to political murder. A Belgian-French invasion of the industrial heartland, the Ruhr, as well as Communist uprisings in Saxony and Thuringia compounded problems (Bittlingmayer 1998). In the years 1919-23, there were 13 government crises, the same number of riots, and three general strikes. In France, there were waves of strikes in 1919 and 1920 , considered by some observers as "a concerted attack upon the structure of bourgeois society" (Lorwin 1968, 334). Nonetheless, these attacks ultimately failed -the trade union activist Merrheim said he "found in France a revolutionary situation without ... any revolutionary spirit in the working classes" (Lorwin 1968: 335).

In the US and Britain, demobilizations and the end of war did not lead to the same degree of extreme instability as in continental Europe. However, the very sharp contractions in output and employment in $1920 / 21$, engineered in part as an attempt to reduce prices and return to the gold standard at prewar parities, led to a considerable rise in worker militancy. This occurred against the background of a considerable strengthening of organized labor. As in the other belligerent countries, the position of labor had strengthened as a result of the war effort - governments recognized unions and encouraged cooperation between them and employers. ${ }^{5}$ Trade union membership in the TUC (Trades Union Congress) soared from 2.2 million in 1913 to 6.5 million in 1920. In our data set, Britain records 39 riots between 1919 and 1922, 12 assassinations, 6 general or politically motivated strikes, and 5 major government crises over the period. The average number of days lost in industrial disputes soared from 4.2 million in 1915-18 to 35.6 million in 1919 23 , the highest recorded value. ${ }^{6}$ Dissatisfaction with the established order could take a number of forms. In the US, there were 5 assassinations and four general or politically motivated strikes in 1919-23. Only one riot broke out, but 17 anti-government demonstrations were recorded. The total number of strikes increased sharply, to 3,630 in 1919 , involving 4.2 million worker's (Foner 1988). Fear of a Communist takeover took the form of the so-called "Red Scare". Following the founding of the Third International in March, two Communist parties were formed in 1919, and quickly became active in propaganda (Schmidt 2000). In response to bombs mailed to politicians by terrorists, a widespread crack-down, led by the Justice Department's Radical Division under J. Edgar Hoover, began.

${ }^{5}$ Cf. Flanders 1968, 8-9; Lorwin 1968, 330-333; Taft 1958, 272-4.

${ }^{6}$ Flanders 1968, p. 65. 


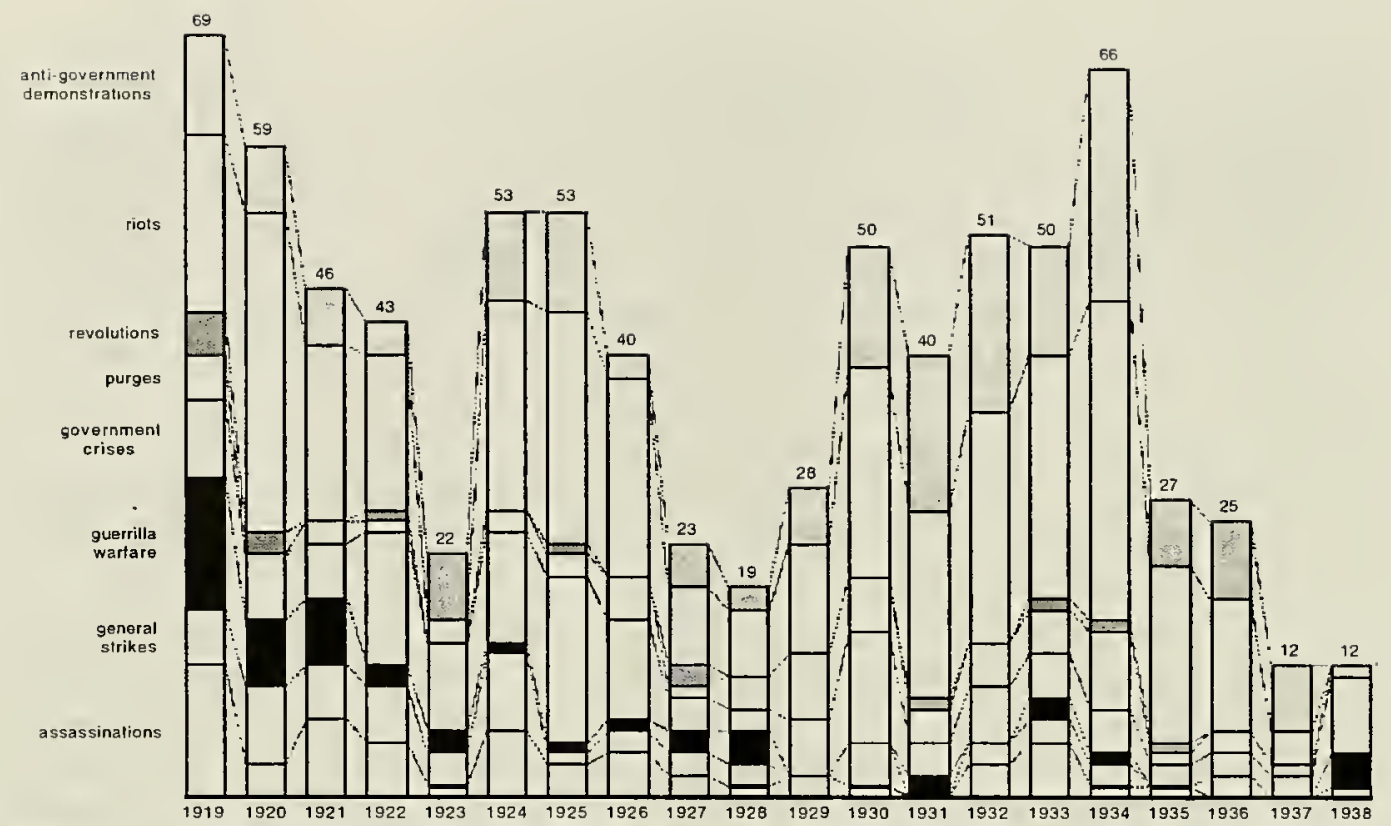

Figure 1: Political and civic unrest in 10-Country-Sample, 1919-1938

The figure shows the total number of events per year, broken down by category. The data is from Banks 1976.

The second half of the 1920s saw a considerable decline in worker militancy and political violence. The 'roaring twenties' brought prosperity to many countries, with some exceptions. The US economy expanded rapidly, France reaped the benefits of currency stabilization under Poincaré, and Germany, with the help of foreign loans, experienced an upsurge in activity after the end of the hyperinflation Eichengreen 1992, Balderston 1993, Borchardt 1991). At the same time, Britain's economy - tied to gold at an overvalued exchange rate - continued to languish (Moggridge 1972). But even in those countries that didn't experience booms, labor militancy was on the wane. With the exception of the general strike in Britain in 1926 (Flanders 1968), labor movements created few troubles. The democracies of central Europe appeared to be stabilizing (Maier 1975). Riots declined to less than one-third their average frequency in the preceding half-decade; government crises, which had been running at an average of more than 10 per year in the early 1920s, fell to 3 in 1927, 2 in 1928, and 5 in 1929.

The second wave of unrest and politically motivated violence began in 1930, with the start of the Great Depression. Over the course of the crisis, industrial output in the US and Germany fell by 40-50 percent from peak to trough, and between a quarter and a fifth of all industrial workers were unemployed over the period 1930-38 (Feinstein, Temin and Toniolo 1997). In the face of massive capital outflows and pressure on reserves as a result of banking panics in Germany, Austria and the US, central banks first tried to defend the gold standard by a policy of deflation (Eichengreen 1992). 
Eventually, more and more countries abandoned the peg, either by devaluing or via a system of capital controls. Countries that remained on gold for a long time experienced the most severe contractions. France, which had initially avoided problems, eventually experienced major difficulties. Faced with a slump that extended into the second half of the 1930 s, it was eventually forced to devalue in June 1937. Britain, which was amongst the first to abandon the gold standard, escaped relatively lightly. ${ }^{7}$ Recovery came faster and in a more robust way to the countries that abandoned gold first (Eichengreen and Sachs 1985).

Economic difficulties were quickly reflected in the politics of the street and the factory floor. The total number of anti-government demonstrations soared from 22 in 1925-29 to 72 in 1930-34; riots rose from 62 to 108 . The number of politically motivated general strikes increased from 7 to 10 . In Germany, there is clear evidence that high rates of unemployment did much to boost the fortunes of the Communist party, already one of the strongest in the world (Falter 1991). Recent research also demonstrates that areas in which incomes contracted particularly sharply saw the largest increase in votes for the Nazis (Stögbauer 2001). In Britain, the Bank of England decided to leave the gold standard instead of raising the (relatively low) discount rate - a decision that can only be understood as an attempt to avoid any further rise in unemployment, and the threat of instability that would follow from it (Eichengreen and Jeanne 1998). Apprehensiveness was accentuated by the mutiny of the Royal Navy in the port of Inverness in 1931.

In the US, the Communist party expanded rapidly during the Great Depression, and union membership soared. As "Hoovervilles" spread around American cities, bitterness against the rich and civic unrest became more widespread. Arthur Schlesinger noted about the year 1931 that "a malaise was seizing many Americans, a sense at once depressing and exhilarating, that capitalism itself was finished" (Schlesinger 1957, 205). The Hoover administration - despite its general willingness to balance the budget by whatever means necessary - opposed a cut in Army infantry units in 1931 because it would "lessen our means of maintaining domestic peace and order." (Schlesinger 1957, 256). In a secret message to Congress, the President urged that troops be exempted from a 10 percent pay cut so that the nation would not have to rely on disaffected troops in case of internal troubles. William Z. Foster, one of the most outspoken Communists in the US, published his book Toward Soviet America in 1932. The party found rich grounds for its agitation amongst the millions of unemployed and impoverished (Schlesinger 1957, 256, 219). In the same year, the so-called Bonus Army marched on Washington - veterans demanding that their bonuses be paid ahead of time. It took cavalry, infantry and tanks,

7 The relatively limited scale of the slump in Britain must be put in the context of its sluggish performance over the period 1920-30. Cf. Feinstein, Temin and Toniolo 1997. 
commanded by General Douglas MacArthur, to regain control (Zinn 1999, 381-2).

Perhaps even more importantly, the crisis rapidly increased the chances of Franklin D. Roosevelt gaining office. While even the most conservative businessmen did not equate this with a communist take-over, worries about the continued existence of "capitalism as we know it" were rampant. As Schlesinger noted, the "New York governor was the only presidential candidate in either major party who consistently criticized business leadership, who demanded drastic (if unspecified) changes in the economic system, who called for bold experimentation and comprehensive planning." (Schlesinger 1957, 290-1) Worries about future economic policy was compounded by the increasing realization that a return to the so-called "New Era" of prosperity and growth was impossible. Faced with growing labor militancy and an increasing willingness to contemplate central planning among the mainstream parties, right-wing radicalism also began to gain a following. Some observers and politicians, including prominent US senators, began to call for a Mussolini-style government, and magazines such as Vanity Fair and Liberty argued the case for a dictatorship Schlesinger 1957, 268).

\section{Unrest and Volatility}

What, then, were the effects of civic unrest and political uncertainty? Average volatility in our sample shows two peaks, one during the early 1920, and a second one during the Great Depression (Figure 2). The high point in 1923 is driven by the extremes of stock price volatility seen during the hyperinflation in Germany, as the difference between the mean and the mode in our sample makes clear. These run broadly in parallel with the upsurges in political violence and worker militancy. In this section, I discuss the extent to which we can find a systematic association between the two. 


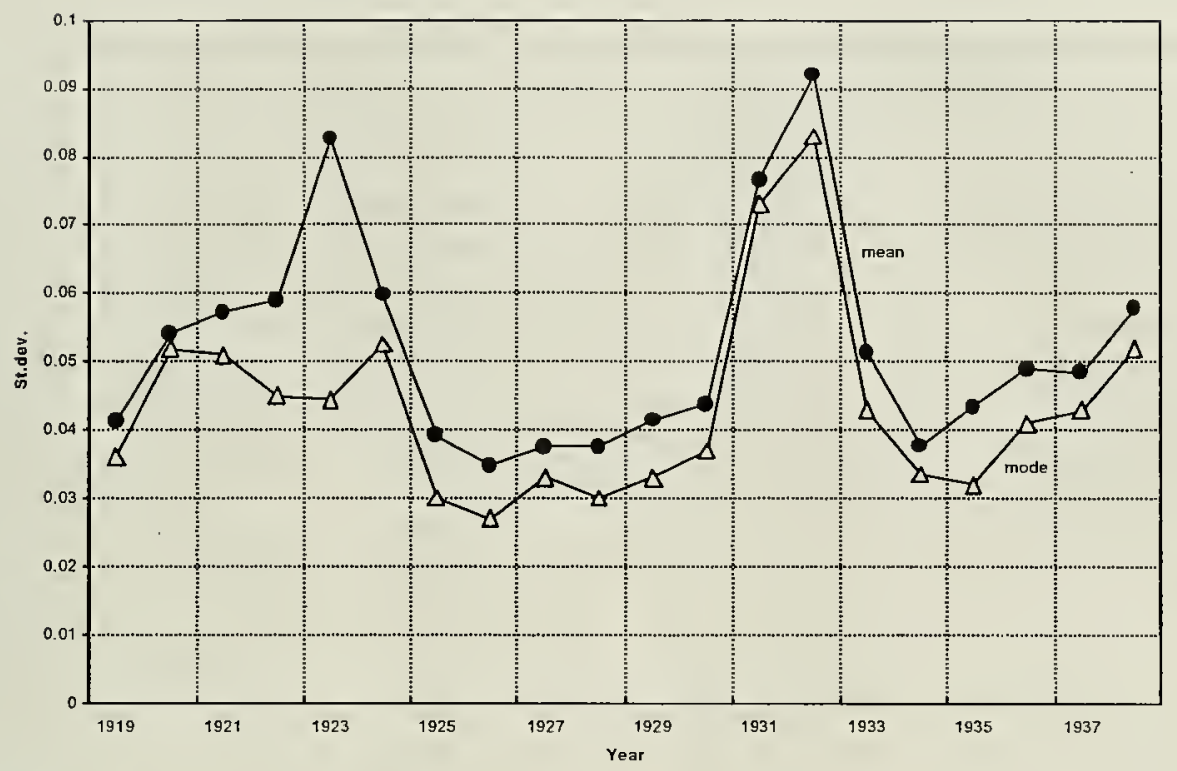

Figure 2: Stock Price Volatility in 10-Country Sample, 1919-1938

The figure plots the mean and median of the monthly standard deviation of continuously compounded real stock returns. For sources, see Data Appendix.

Some of our measures of political instability appear highly correlated with the volatility of stock returns, as well as with each other. Table III gives the results. Assassinations, strikes, acts of guerrilla warfare, riots, purges and revolutions are frequently correlated with each other. The correlation of stock price volatility with government crises is also evident and significant at the 5 percent level, as is the impact of riots and demonstrations (significant at the 1 percent level). Share price volatility is also strongly and significantly correlated with the volatility of inflation. ${ }^{8}$

8 This is in contrast to the results by Schwert (1989b), who finds that the predicted volatility of the producex price index is only weakly correlated with stock price variability. Our results are largely unchanged when we use the conditional variance of inflation from a GARCH $(1,1)$ model instead of actual variability of price changes. 


\section{Table III}

\section{Correlations of Indicators of Political Instability, Share Price} Volatility, and the Volatility of Inflation

The number of events in each country per year is correlated with the volatility of continuously compounded monthly real return in the same year, and the volatility of monthly rates of inflation. ASS is the number of assassinations per year, STRIKE the number of politically motivated or general strikes, GUE are acts of guerrilla warfare, CRISIS refers to the number of government crises, PURGES are the violent crackdowns on the opposition, by the government or forces sympathetic to the government, RIOT is the number of violent demonstrations and riots, $\mathrm{REV}$ is the number of attempted revolutions (successful or not), and DEMO is the number of anti-government demonstrations not directed against foreign powers. For sources, $c f$. the Data Appendix.

\begin{tabular}{lccccccccc}
\hline & STRIKE & GUE & CRISIS & PURGES & RIOT & REV & DEMO & SVOL & PVOL \\
\cline { 2 - 9 } ASS & $0.26^{\star \star}$ & $0.35^{\star \star}$ & $0.15^{*}$ & $0.24^{\star \star}$ & $0.27^{\star \star}$ & $0.18^{\star}$ & 0.10 & 0.01 & -0.01 \\
STRIKE & 1.00 & $0.35^{\star \star}$ & $0.16^{\star}$ & 0.04 & $0.38^{\star \star}$ & $0.23^{\star \star}$ & $0.30^{\star \star}$ & 0.13 & 0.10 \\
GUE & & 1.00 & 0.10 & 0.08 & $0.30^{* \star}$ & $0.41^{* \star}$ & 0.00 & -0.01 & -0.01 \\
CRISIS & & & 1.00 & 0.04 & $0.32^{\star \star}$ & $0.19^{\star}$ & 0.15 & 0.15 & 0.05 \\
PURGES & & & 1.00 & 0.09 & 0.10 & 0.11 & -0.08 & -0.03 \\
RIOT & & & & & 1.00 & $0.35^{\star \star}$ & $0.46^{\star \star}$ & 0.21 & -0.00 \\
REV & & & & & & 1.00 & 0.05 & -0.02 & -0.01 \\
DEMO & & & & & & & 1.00 & $0.24^{\star \star}$ & 0.01 \\
SVOL & & & & & & & & 1.00 & $0.68^{\star \star}$ \\
\hline
\end{tabular}

To test for connections between the degree of political uncertainty and stock market volatility more formally, I estimate panel regressions of the type:

$\sigma_{i t}=\alpha_{i}+\beta_{1} X_{i t}+\beta_{2} P_{i t}+\varepsilon$

where $\sigma_{i t}$ is the standard deviation of continuously compounded monthly real stock returns in country $i$ at time $t, X_{i t}$ is a set of macroeconomic controls, and $P_{i t}$ are the indicators of political and social instability discussed above. Table IV reports the results of estimating (1) with generalized least squares for the full sample over the period 1919-1939. Some of the indicators of political unrest emerge as highly significant. Anti-government demonstrations are important in driving up volatility, as are government crises. Collinearity between the demonstrations variable and those for riots and strikes leads to some imprecisely estimated coefficients (Table IV, eq. 1). I therefore calculated a summary variable, CHAOS, equal to the (unweighted) sum of strikes, riots and demonstrations. It emerges as consistently and highly significant. To illustrate the nature of the variable, consider Figure 3, which plots the component series of CHAOS alongside stock price volatility. 


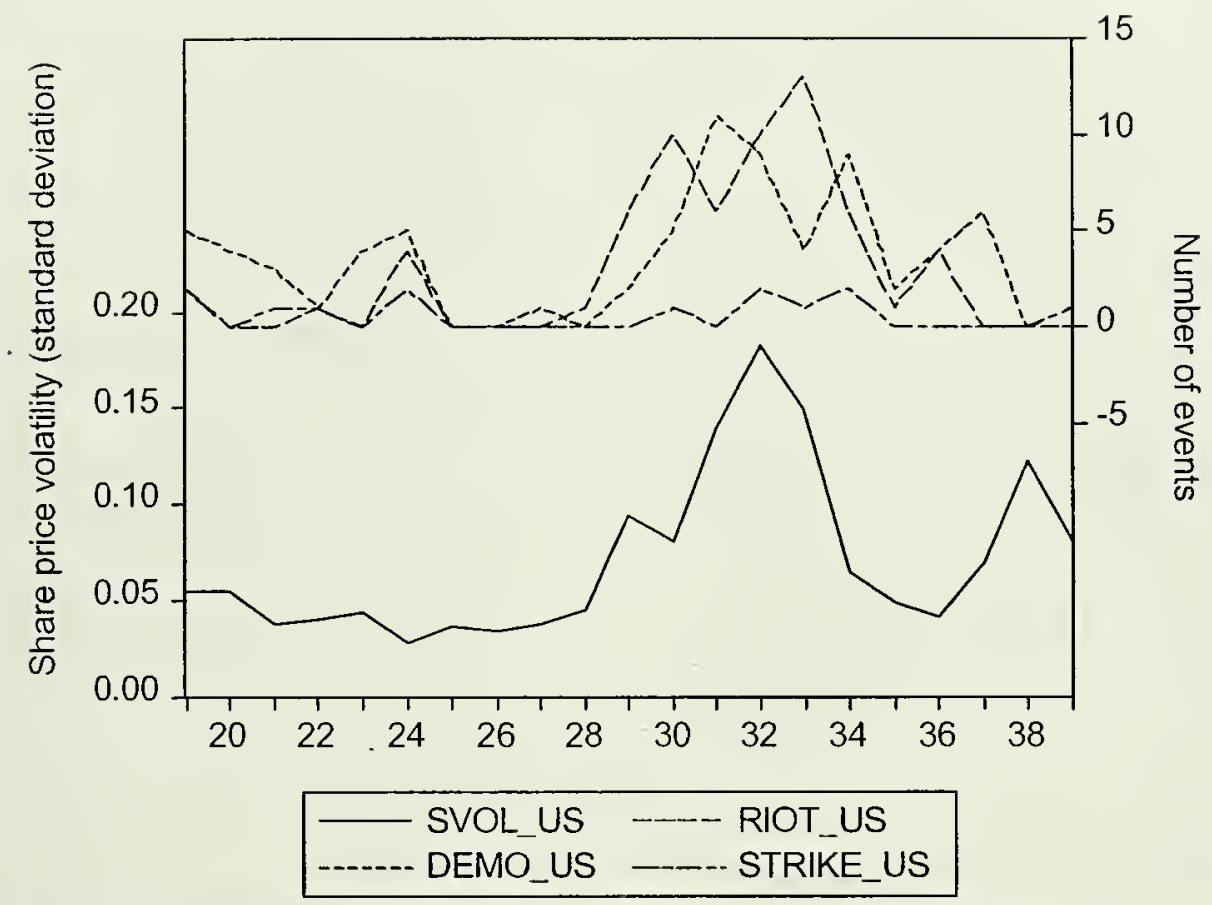

Figure 3: Share Price Volatility and Unrest in the United States

The same is true of PURGE, which indicates that crackdowns on militants significantly reduced the volatility of equity values. Higher inflation variability leads to greater volatility of stock prices. The use of fixed effects has little effect on our results. These effects are large in an economic sense. A one standard deviation increase in the number of demonstrations would have raised stock price volatility by 14 percent; a one standard deviation rise in our CHAOS variable has an impact of 22 percent. For the PURGE variable, on the other hand, the effect is a reduction by 9.5 percent. While we are able to explain between 7 and 8 percent of the total variation in stock price volatility with political variables, inflation volatility alone can explain up to 45 percent. The fixed effect dummies add another 9 percent. The results demonstrate that, while civic unrest and politically motivated violence clearly had an effect on stock prices during the interwar years, it's explanatory power is not overwhelming. Controlling for the level of inflation does not alter this result (equation 11). ${ }^{9}$ A number of variables are not significant - as is the case for changes in the executive (EXECCH), the number of elections (NELECT), the number of assassinations (ASS) and revolutions (REV).

9 Note, however, that the negative and significant coefficient is not robust to changes in the specification - estimating in logs (to cope with the extreme values observed during the German hyperinflation) yields an insignificant coefficient. 


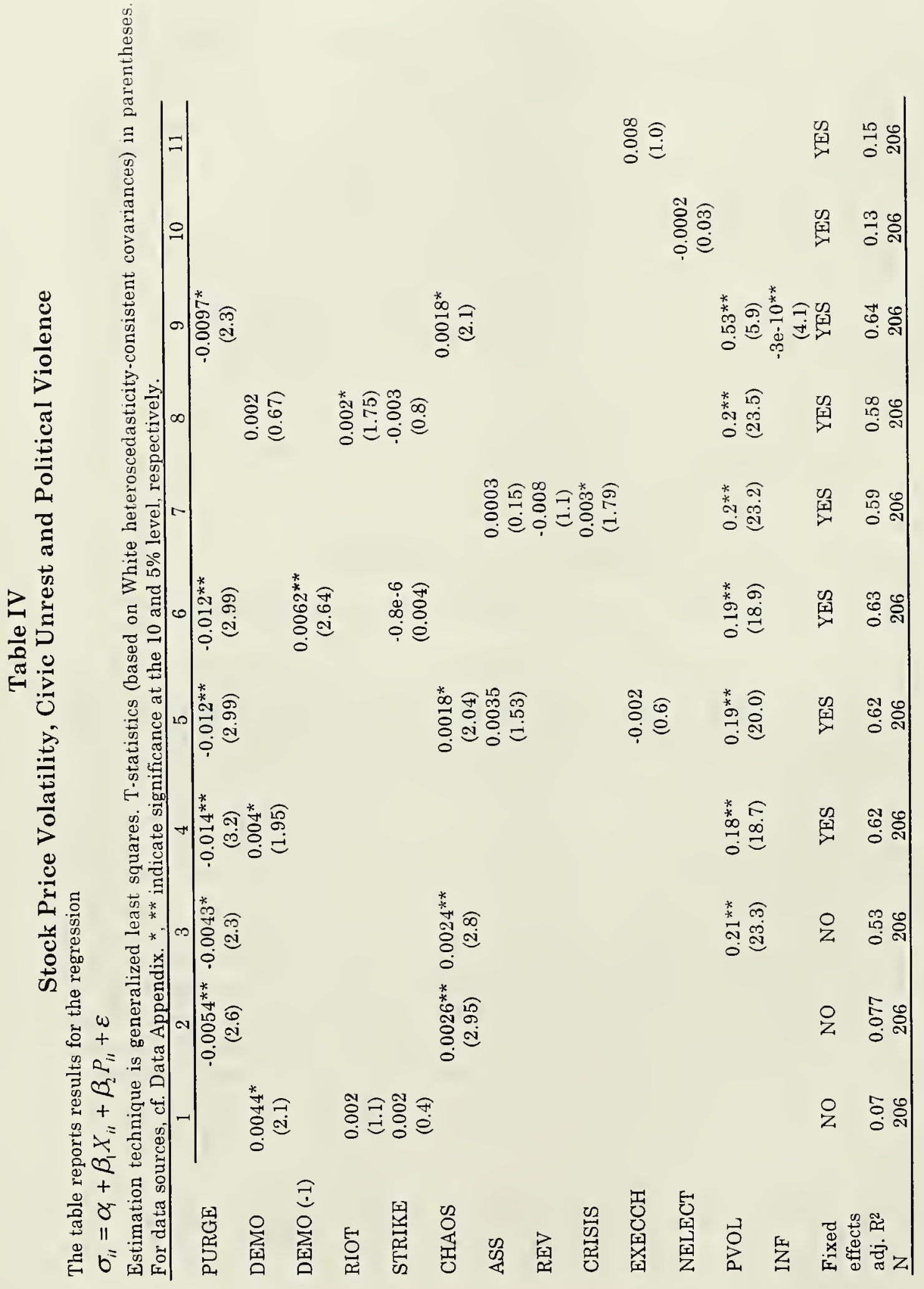


An obvious concern with our regressions in Table IV are possible correlations in the error terms. As our historical narrative stressed, the risk of revolutions and other challenges to the established economic order was often highly correlated across countries - as could be seen in the wave of strikes and attempts at revolution after the end of World War I, or during the Great Depression. To ignore the correlation in the error terms would be to overlook a significant element in the history of the period. To deal with the issue, I estimate seemingly unrelated regressions (SUR) of our baseline specification. Table $\mathrm{V}$ gives the results. The coefficient for the indicators of civic unrest are often somewhat smaller, but more tightly estimated than under GLS. The negative and significant coefficient on PURGE is broadly confirmed, as is the volatility-increasing impact of CHAOS. DEMO has a significant coefficient in 2 out of 3 cases, and CRISIS emerges again as significant. PVOL is also highly correlated with stock price volatility. ${ }^{10}$ The main difference with the results reported in Table IV is that there is now a clearer indication of the number of elections in any one year increasing volatility (eq. 11). Also, increased numbers of changes in the executive appear to undermine the stability of share prices (eq. 10). These results are similar to the recent finding that share price volatility in emerging markets is systematically higher during elections (Mei 1999).

10 This is in line with recent findings by $\mathrm{Hu}$ and Willett 2000 , who document evidence in favour of the variability hypothesis. 


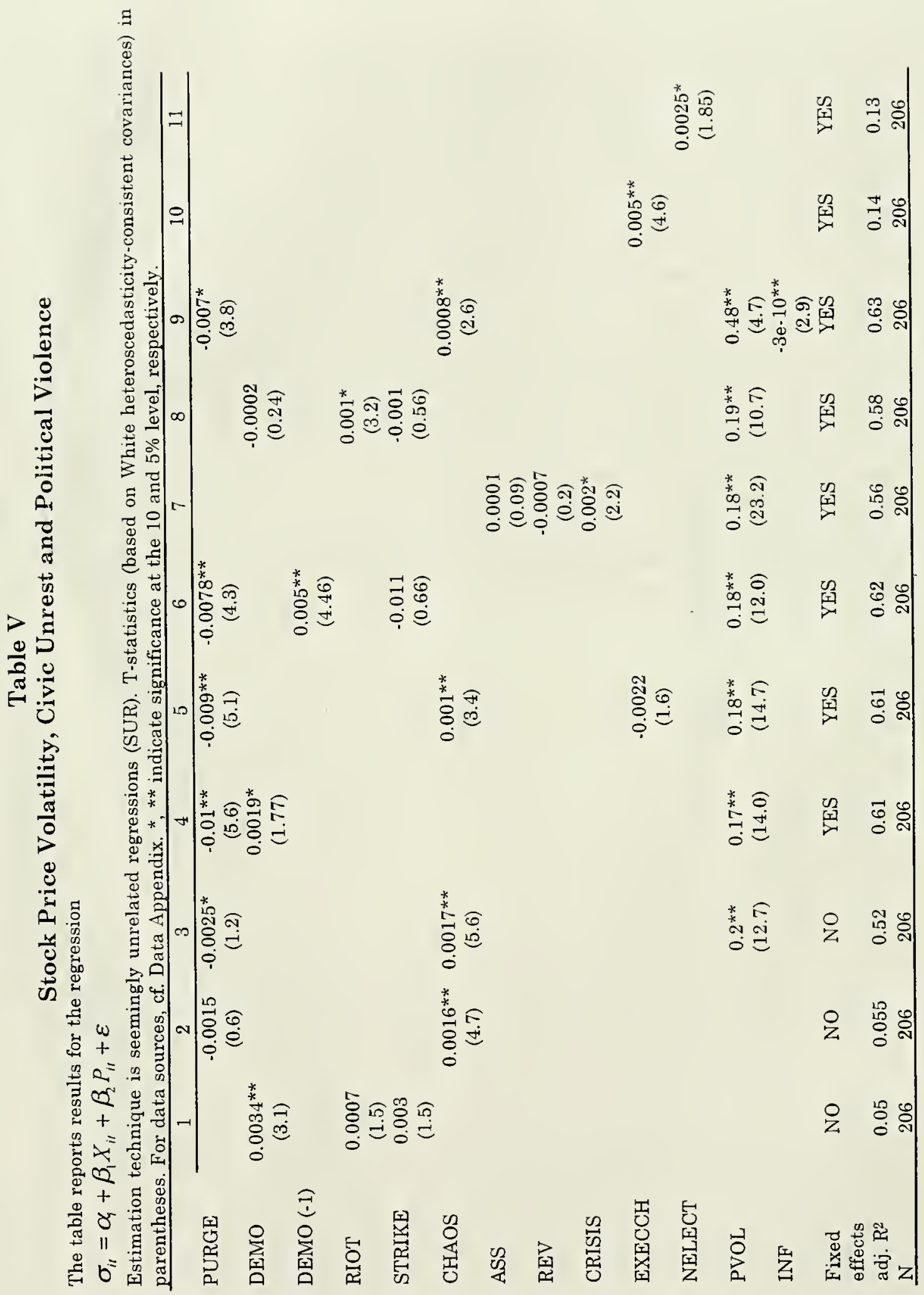


Another possible objection is that results might be driven by the inclusion of Germany in our sample, where the connection between stock price volatility and political chaos was particularly close (Bittlingmayer 1998). I therefore re-estimate the principal results of Table IV and Table V excluding the case of Germany (Table VI). The coefficients on CHAOS appear largely unchanged if marginally smaller, and PVOL again emerges as a large and significant factor contributing to higher volatility. RIOT and DEMO also contribute to higher variability of stock returns in all specifications except eq. (6), where we estimate in logs. There, the lagged value of the number of anti-government demonstrations is not significant.

\section{Table VI}

\section{Stock Price Volatility and Civic Unrest - 9 Country Sample}

The table reports results for the regression

$$
\sigma_{t}=\alpha_{i}+\beta_{1} X_{i t}+\beta_{2} P_{i t}+\varepsilon
$$

Estimation technique is seemingly unrelated regressions (SUR). T-statistics (based on White heteroscedasticity-consistent covariances) in parentheses. For data sources, cf. Data Appendix. ${ }^{*},{ }^{* *}$ indicate significance at the 10 and $5 \%$ level, respectively. The sample contains all countries except Germany. The dependent variable is $\sigma_{t}$ except in eq. (6), where it is $\ln \left(\sigma_{\mathrm{t}}\right)$.

\begin{tabular}{|c|c|c|c|c|c|c|}
\hline & 1 & 2 & 3 & 4 & 5 & 6 \\
\hline PURGE & $\begin{array}{c}0.00036 \\
(0.13)\end{array}$ & $\begin{array}{c}0.0003 \\
(0.11)\end{array}$ & $\begin{array}{l}-4 \mathrm{e}-5 \\
(0.02)\end{array}$ & & & \\
\hline $\operatorname{DEMO}(-1)$ & & & & $\begin{array}{c}0.0048^{* *} \\
(4.7)\end{array}$ & $\begin{array}{c}0.0048^{* *} \\
(4.7)\end{array}$ & $\begin{array}{c}0.0099 \\
(0.56)\end{array}$ \\
\hline RIOT & & & & $\begin{array}{c}0.0007^{*} \\
(2.45)\end{array}$ & $\begin{array}{c}0.0008^{*} \\
(2.4)\end{array}$ & $\begin{array}{c}0.037^{\star * *} \\
(2.6)\end{array}$ \\
\hline STRIKE & & & & & $\begin{array}{c}1.5 e-5 \\
(0.008)\end{array}$ & $\begin{array}{c}-0.007 \\
(0.3)\end{array}$ \\
\hline CHAOS & $\begin{array}{c}0.0012^{\star *} \\
(3.9)\end{array}$ & $\begin{array}{c}0.0007^{* *} \\
(2.6)\end{array}$ & $\begin{array}{c}0.0007^{* *} \\
(2.6)\end{array}$ & & & \\
\hline PVOL & $\begin{array}{c}0.53^{\star \star} \\
(4.02)\end{array}$ & $\begin{array}{c}0.37^{\star \star} \\
(2.3)\end{array}$ & & $\begin{array}{l}0.31^{*} \\
(1.78)\end{array}$ & $\begin{array}{c}0.32^{*} \\
(1.8)\end{array}$ & $\begin{array}{l}0.16^{\star *} \\
(2.97)\end{array}$ \\
\hline $\begin{array}{l}\text { Fixed } \\
\text { effects }\end{array}$ & NO & YES & YES & YES & YES & YES \\
\hline adj. $R^{2}$ & 0.08 & 0.27 & 0.27 & 0.34 & 0.34 & 0.32 \\
\hline $\mathrm{N}$ & 182 & 182 & 182 & 182 & 182 & 182 \\
\hline
\end{tabular}

Using the standard deviation of monthly returns in country $i$ at time $t$ as a dependent variable generates easily interpretable results. However, since the days of pioneering studies (such as Officer 1973) that used a similar approach, more advanced techniques have become 
available. ${ }^{11}$ One of the well-observed regularities of equity returns is time-varying volatility - large (positive or negative) returns tend to be followed by large (positive or negative) returns. Adding lagged values of SVOL in the regressions in Table IV and Table $\mathrm{V}$ does not change our results. An alternative approach is to derive conditional variances from GARCH models, and to use these as dependent variables.

\section{Table VII}

\section{Conditional Stock Price Volatility and Civic Unrest}

The table reports results for the regression

$\sigma_{i t}=\alpha_{1}+\beta_{1} X_{i t}+\beta_{2} P_{i t}+\varepsilon$

Estimation technique is seemingly unrelated regressions (SUR). T-statistics (based on White heteroscedasticity-consistent covariances) in parentheses. For data sources, cf. Data Appendix. The sample contains all countries except Germany. The dependent variable is the conditional variance from $\operatorname{GARCH}(1,1)$ models for each of the 10 countries. ${ }^{*},{ }^{* *}$ indicate significance at the 10 and $5 \%$ level, respectively.

\begin{tabular}{|c|c|c|c|c|c|c|c|}
\hline & 1 & 2 & 3 & 4 & 5 & 6 & 7 \\
\hline PURGE & $\begin{array}{c}-0.0004^{\star \star} \\
(3.4)\end{array}$ & & & & $\begin{array}{c}0.0002 \\
(1.2)\end{array}$ & & \\
\hline DEMO & & $\begin{array}{c}0.0006^{* *} \\
(5.0)\end{array}$ & & & & $\begin{array}{c}0.0005^{* *} \\
(4.8)\end{array}$ & \\
\hline RIOT & & & $\begin{array}{c}0.0004^{* *} \\
(5.9)\end{array}$ & & & & \\
\hline CHAOS & & & & $\begin{array}{c}0.0003^{\star \star} \\
(6.2)\end{array}$ & & & $\begin{array}{c}0.0002^{\star \star *} \\
(3.6)\end{array}$ \\
\hline PVOL & & & & & $\begin{array}{r}0.07^{\star \star} \\
(10.3)\end{array}$ & $\begin{array}{l}0.07^{\star \star \star} \\
(11.1)\end{array}$ & $0.07^{\star \star}$ \\
\hline $\begin{array}{l}\text { Fixed } \\
\text { effects }\end{array}$ & NO & NO & NO & NO & NO & NO & YES \\
\hline adj. $R^{2}$ & 0.003 & 0.004 & 0.01 & 0.01 & 0.61 & 0.64 & 0.66 \\
\hline $\mathrm{N}$ & 188 & 188 & 188 & 188 & 188 & 188 & 185 \\
\hline
\end{tabular}

Table VII reports the results of re-estimating our models using the conditional variances from $\operatorname{GARCH}(1,1)$ models as the dependent variables. The coefficients on our indicators of unrest and militancy are estimated tightly. If anything, chaos and turmoil are more helpful in explaining conditional variances than the unadjusted ones - a one standard deviation rise in CHAOS increases the conditional variance by 27 percent relative to its mean, while a one standard deviation change in DEMO has an impact of 20 percent (the respective values for unadjusted variances were 22 and 14 percent).

Political chaos and unrest, especially acts of labor militancy aimed against the government of the day and the political system more

11 For an overview, cf. Campbell, Lo and MacKinlay 1997, ch. 12.2. 
broadly, did contribute to higher volatility of stock returns during the interwar period. While the effect is not uniformly strong for all indicators of instability, a number of variables emerge as consistently significant. These are the number of strikes, riots and anti-government demonstrations. Independently of the estimation strategy used, the inclusion of fixed effects, and the selection of sub-samples, these appear to be a considerable part of the story about high and increasing variability of stock returns during the Great Depression in 10 relatively advanced countries.

\section{The Risk of Revolution}

So far, we have implicitly used an indirect mapping from political violence and worker unrest to stock price volatility. The logic of our argument, however, suggests that the main cause of the impact of any political unrest variable on stock price volatility should be changes in the expected chances of survival of the established economic and political order. I therefore examine the extent to which these variables would actually have been useful in predicting revolutions - either attempted ones or those that succeed. Logistic regressions show that indicators of civic unrest and anti-government militancy are highly useful predictors of revolutions. From these regressions, we can derive the threat of revolution - similar to the threat of takeover examined in the corporate finance literature (Agrawal and Knoeber 1998). The probability of an attempted overthrow of the government can then be used to explain stock price volatility. I find that changes in the likelihood of revolutions alone is sufficient to explain about 7-20 percent of the variation in stock price volatility.

There are 14 revolutions in our data set - as well as 194 annual observations at the country level showing no revolution. As a first step, we model the likelihood of an (attempted) violent overthrow of the government, depending on the indicators of political instability and violence used above. The predicted values are then correlated with stock price volatility. This is essentially a data reduction strategy, similar to factor analysis - except that our new exogenous variable has a clear interpretation. In Table VIII, I report the results for logistic regressions with revolutions as the dependent variable. Multicollinearity between the exogenous variables, as noted above, sometimes leads to insignificant coefficients. Independent of the specification used, we find that the number of government crises in any one year is an important predictor of the risk of a violent bid for power. Riots are also highly significant in all regressions with the exception of (3). Purges and other acts of violent suppression are clearly more frequent in the run-up to revolutionary events, as are acts 
of guerrilla warfare. While the Pseudo- $R^{2} \mathrm{~s}$ are never high, the percentage of events correctly predicted is always above 90 percent.

\section{Table VIII}

The Risk of Revolution - Logistic Regressions

The dependent variable is a dummy variable $D_{t}=1$ if a (attempted) violent overthrow of the established government occurred, $\mathbf{0}$ otherwise. The Pseudo- $\mathrm{R}^{2}$ is the Nagelkerke- $\mathrm{R}^{2}$. Wald statistics in parentheses. For data sources, cf. Data Appendix. ${ }^{*}, * *$ indicate significance at the 10 and $5 \%$ level, respectively.

\begin{tabular}{lcccc}
\hline & 1 & 2 & 3 & 4 \\
\cline { 2 - 5 } STRIKE & 0.47 & 0.49 & 0.038 & \\
& $(1.67)$ & $(1.7)$ & $(0.006)$ & \\
CRISIS & $0.397^{* *}$ & $0.43^{* *}$ & $0.45^{* *}$ & $0.385^{* *}$ \\
& $(4.99)$ & $(5.2)$ & $(5.45)$ & $(4.7)$ \\
RIOT & $0.12^{*}$ & $0.14^{*}$ & 0.096 & $0.16^{* *}$ \\
& $(3.02)$ & $(3.3)$ & $(1.24)$ & $(5.8)$ \\
PURGES & & $0.42^{*}$ & 0.42 & $0.4^{*}$ \\
& & $(2.8)$ & $(2.42)$ & $(2.7)$ \\
DEMO & & -0.12 & -0.008 & \\
& & $(0.4)$ & $(0.001)$ & \\
ASS & & & -0.14 & \\
GUE & & & $(0.14)$ & \\
& & & $0.76^{* *}$ & \\
Constant & $-3.5^{* *}$ & $-3.7^{* *}$ & $-3.9)$ & \\
& $(61.4)$ & $(53.9)$ & $(51.0)$ & $-3.6^{* *}$ \\
Pseudo-R & 0.162 & 0.192 & 0.289 & 0.17 \\
\% correctly & 93.75 & 93.75 & 93.27 & 92.79 \\
predicted & & & & \\
$\chi^{2}$ & 13.5 & 16.1 & 24.85 & 14.3 \\
\hline
\end{tabular}

The risk of revolution varies widely in our sample. Based on the predicted values from regression (1), Germany starts the period with a 22 percent risk of another revolution, and witnesses a peak of over 45 percent in the period immediately following the stabilization of the currency in 1924/25. France, on the other hand, reaches the highest risk level in 1932, when the risk of revolution surges to 40 percent. In line with expectations, Switzerland is not a hothouse of social unrest, consistently showing a risk of revolution below 3.5 percent during the period. The mean risk in our sample as a whole climbs to an all-time high in 1920, when it reaches 14.7 percent. After falling in the 1920 s to around 4.5 percent -- similar to Switzerland - it almost doubles to 8.4 percent in 1932. Using the forecasts from regression (4) again suggests that the all-time peak is in 1920 , at 11.9 percent, but that by 1932 , the second-highest value for the whole period is reached -9.1 percent. The medians tell a similar story. In 1932, they reach local maxima that are 
between one fifth and one half higher than the average values for the period as a whole. In line with the writings of many contemporary observers and later historians, we also find evidence that 'strong' authoritarian governments - where parliaments had only a small role to play - were seen to provide a degree of safety against the risk of revolution (Turner 1985, Nolte 1963). When we correlate the degree of parliamentary responsibility (again taken from the Banks data set) with the risk of revolution, we find a clear and positive association with both the risk of revolutions and their actual number. ${ }^{12}$

From the logistic regressions in Table VIII, we derive the predicted probability of a revolution occurring in country $j$ at time $t$. Is this new variable significantly correlated with stock price volatility? To examine this question, we use the predicted likelihood of a violent attempt to overthrow the government as a regressor in equations similar to (1). Table IX gives the results. There is a significant and strong effect independent of the estimation strategy and the specification of the variables. A rise by one standard deviation in the risk of revolutions increases average stock price volatility by 0.4 to 0.7 percent -- equivalent to between 8 and 14 percent relative to the mean. This is independent of controlling for the effects of price volatility, or other socio-political indicators such as the frequency of purges (which again reduce volatility). We therefore find strong and consistent support for the Schwert/Merton hypothesis. It seems natural to ask if the "volatility puzzle" can thus be resolved. Figure 4 in the appendix plots the residuals from our regression (5) in Table IX. They do not remain within the 95 percent confidence interval for the entire time in all countries. Germany experienced a significant unexplained spike in $1923 / 24$, for example, and again in 1931, whereas the UK shows deviations in 1931 and 1938. The currency crises in 1931 are probably significant contributors to these levels of volatility. ${ }^{13}$ In the US,

12 I use variable 121 to measure the extent of parliamentary responsibility. Cf. the Data Appendix for definitions. Note, however, that only three countries in our dataset receive less than the maximum score (of 3 ) in our sample - Germany, Italy, and Switzerland.

13 I tested for the possibility that countries on the gold standard had systematically lower share price volatility, or that transitions of the monetary regime raised volatility. There was no consistent and large effect. 
considerable residuals remain for $1929,1931,1932$ and 1938 . While this is clearly unsatisfactory, it also suggests that our model explains stock price volatility sufficiently well to reduce the extraordinary scale of variability in 1932 to a relatively unspectacular deviation from predicted levels. 
닌

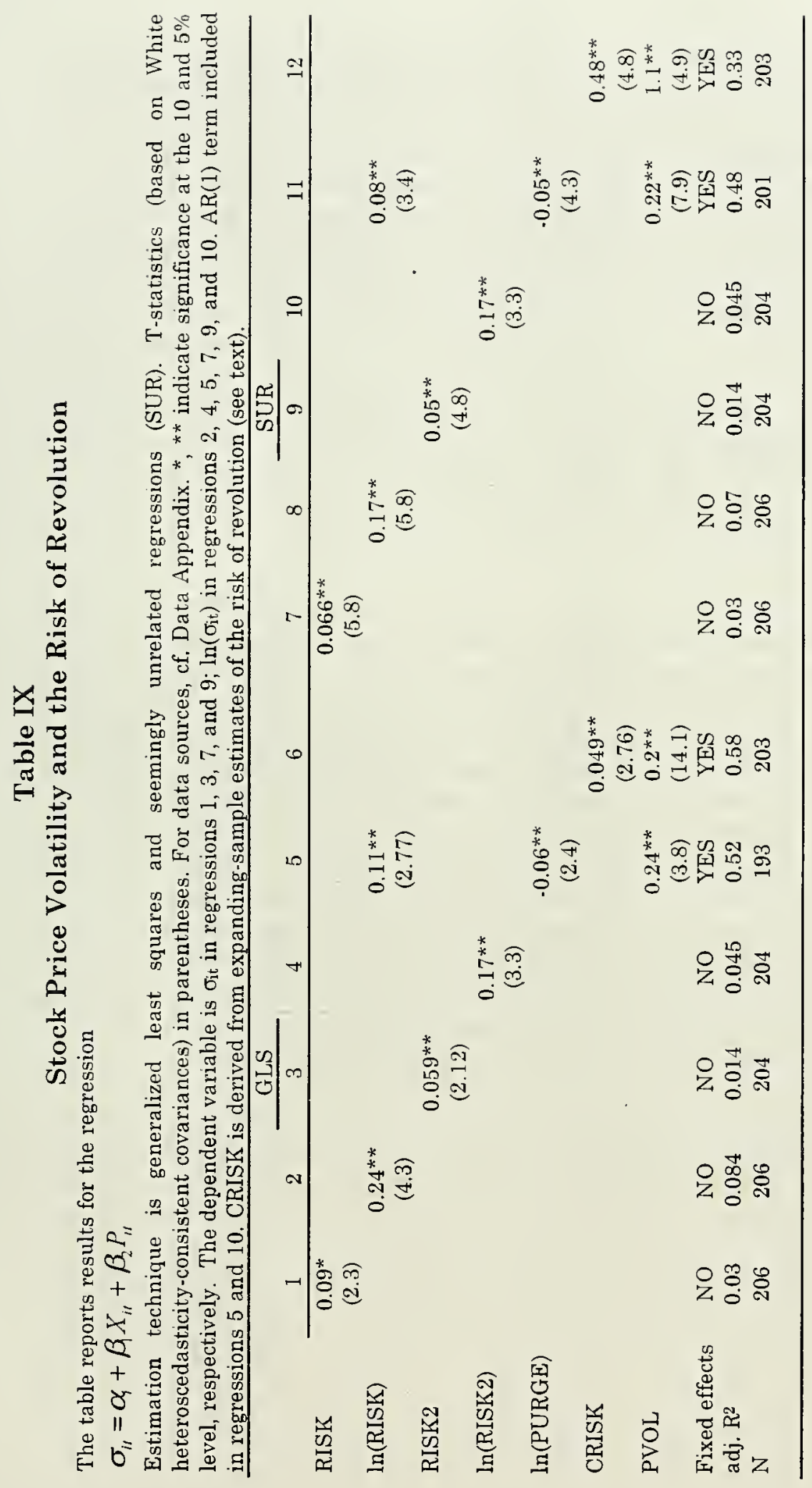


By deriving estimates of the probability of revolution from specifications such as those used in Table VIII, we implicitly assume that agents at the time had information for the entire period 19191939. An alternative approach re-estimates the logistic regressions for every year, expanding the sample as time goes by. The probability of revolution in year $\mathrm{t}$ will only be assessed based on information for the period 1919 up to and including year t. I initially begin with the period 1919 to 1922 (to preserve a minimum number of degrees of freedom), using specification 1 from Table VIII. The forecasts from these regressions for each country in each one of these years form the first entries for a new variable, CRISK. For 1923, I then estimate based on 1919-1923, deriving the probability of revolution in each country for that year. Table IX reports the results of using these expandingsample forecasts. The earlier findings linking political uncertainty and the risk of revolution to stock market volatility are considerably strengthened, with larger coefficients that are also more statistically significant.

Similar results can be obtained if we use the conditional variances from $\mathrm{GARCH}(1,1)$ models, as in our previous exercise with the variables on demonstrations, riots and strikes. I employ the three alternative definitions of the risk of revolutions, as before. As a further robustness test, I add an AR(1) term to our specification. Table $\mathrm{X}$ gives the results. Results are largely unchanged. The danger of a violent overthrow of the established order always leads to higher stock market volatility - a one standard deviation increase in the risk of revolution (RISK) is associated with a 18 percent higher conditional variances. The overall share of variation explained with the revolutionary threat model is not very large, but the size and significance of the effect is unchanged if we include fixed effects or the variance of inflation rates. The only variable whose statistical significance appears somewhat fragile is CRISK (based on expanding-sample forecasts of the probability of revolution), which is not significant in eq. (9). 


\section{Table X}

Conditional Stock Price Volatility and the Risk of Revolution

The table reports results for the regression

$\sigma_{u}=\alpha_{1}+\beta_{1} X_{u}+\beta_{2} P_{i t}+\varepsilon$

Estimation technique is seemingly unrelated regressions (SUR). T-statistics (based on White heteroscedasticity-consistent covariances) in parentheses. For data sources, cf. Data Appendix. The dependent variable is the conditional variance from GARCH $(1,1)$ models for all $10 .{ }^{*},{ }^{* *}$ indicate significance at the 10 and $5 \%$ level, respectively.

\begin{tabular}{|c|c|c|c|c|c|c|c|c|c|}
\hline & 1 & 2 & 3 & 4 & 5 & 6 & 7 & 8 & 9 \\
\hline R1SK & $\begin{array}{c}0.011^{\star *} \\
(7.1)\end{array}$ & & & $\begin{array}{c}0.004^{* *} \\
(2.6)\end{array}$ & & & $\begin{array}{c}0.0006^{* *} \\
(2.5)\end{array}$ & & \\
\hline R1SK2 & & $\begin{array}{c}0.011^{* *} \\
(7.1)\end{array}$ & & & $\begin{array}{c}0.001^{*} \\
(1.7)\end{array}$ & & & $\begin{array}{c}0.0009^{* *} \\
(3.44)\end{array}$ & \\
\hline CRISK & & & $\begin{array}{c}0.008^{* *} \\
(3.8)\end{array}$ & & & $\begin{array}{c}0.007^{* *} \\
(3.5)\end{array}$ & & & $\begin{array}{c}0.0002 \\
(0.87)\end{array}$ \\
\hline PVOL & & & & $\begin{array}{l}0.06^{\star *} \\
(11.2)\end{array}$ & $\begin{array}{c}0.06^{* *} \\
(9.6)\end{array}$ & $\begin{array}{l}0.07^{\star \star *} \\
(10.9)\end{array}$ & $\begin{array}{c}0.026^{* *} \\
(5.9)\end{array}$ & $\begin{array}{c}0.024^{\star \star} \\
(5.5)\end{array}$ & $\begin{array}{c}0.026^{* *} \\
(5.8)\end{array}$ \\
\hline $\operatorname{AR}(1)$ & & & & & & & $\begin{array}{c}0.87^{\star *} \\
(22.8)\end{array}$ & $\begin{array}{c}0.89^{\star *} \\
(25.6)\end{array}$ & $\begin{array}{l}0.87^{* *} \\
(23.0)\end{array}$ \\
\hline $\begin{array}{l}\text { Fixed } \\
\text { effects }\end{array}$ & NO & $\mathrm{NO}$ & $\mathrm{NO}$ & YES & YES & YES & NO & NO & NO \\
\hline adj. $R^{2}$ & 0.002 & 0.0006 & 0.008 & 0.65 & 0.63 & 0.66 & 0.63 & 0.61 & 0.63 \\
\hline $\mathrm{N}$ & 188 & 188 & 188 & 185 & 183 & 185 & 176 & 174 & 176 \\
\hline
\end{tabular}

So far, we have mainly focussed on the strength of the threat that could be mounted by disaffected segments of society - as might have been perceived by stockholders. However, in order to analyse the chances of capitalism's survival, the strength of the current system should arguably matter in addition to the degree of turmoil and unrest created by the opposing forces. Parliamentary systems vary widely in the extent to which they are able to produce strong governments. While systems of proportional representation often allow even very small splinter groups to gain seats in parliament, other systems (such as those with a first-past-the-post rule for MPs) create strong majorities out of relatively small absolute differences in voter behavior. During our period, Weimar Germany marks one extreme - parties that managed to poll 60,000 votes in the entire country were represented in the Reichstag. At the opposite end of the spectrum, Britain's electoral rules continued to return governments with sizeable parliamentary majorities, even if the voting was close. Did it matter? For our hypothesis to be confirmed, we would expect that greater fractionalization should lead to more instability - for any given revolutionary threat, the established order should be in greater risk of decline and fall. 


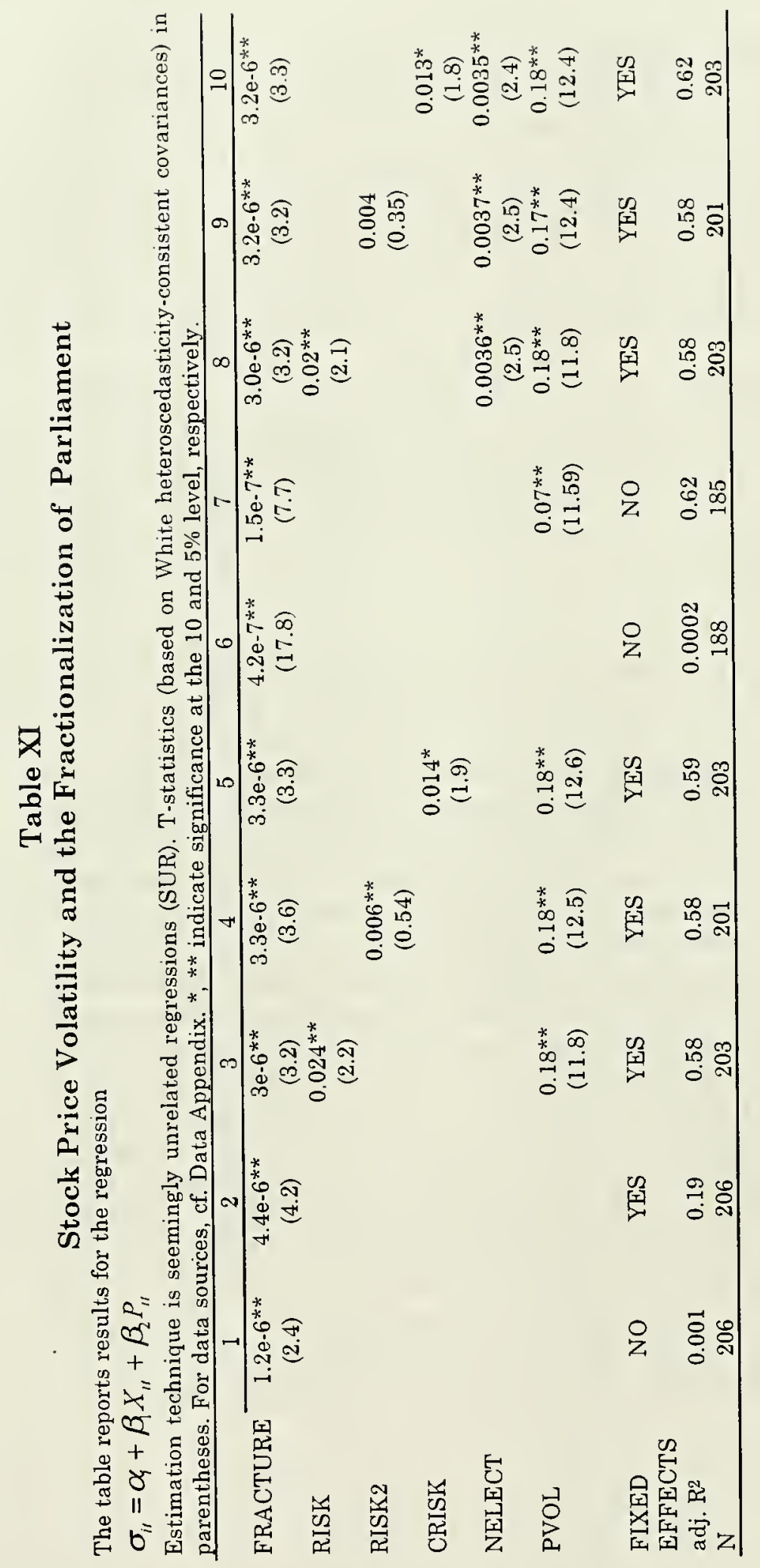


Table XI reports the results of regressing stock price volatility on the fractionalization index. The weaker the parliamentary system, the greater the instability in national stock markets during the interwar period. The effect is unambiguous in terms of statistical significance, even if the size of the coefficient varies. Also, once we control for the type of parliamentary system, the number of elections (which, a priori, should also be associated with greater volatility) has the expected sign. A one standard deviation rise in fractionalization increases share price volatility by 14.5 percent relative to its mean.

Schwert (1989b) uses nominal returns in his calculations. When price changes are not too dramatic, this is unlikely to introduce biases. In the baseline results, I used real returns to avoid the extreme impact that inflation had in some of the countries in our sample - it would be incorrect to infer that share price volatility was particularly high if most of the variance resulted from greater inflation variability. To examine the robustness of our results, I re-estimated the main results using the standard deviation of nominal monthly returns in any given year as the dependent variable. Table XV and Table XVI in Appendix II give the results (with and without the years of the German hyperinflation included). The results for our political variables are largely unchanged, and never become insignificant, with two exceptions. The variable for the number of anti-government demonstrations is not significant in the full sample, but strongly so if we exclude the hyperinflation. In the sample that excludes the German observations for 1919-24, the effect of purges is not tightly estimated, and one of the tree measures of the risk of revolution is marginally below statistical significance at customary levels.

\section{Omitted Variable Bias}

Reverse causation - with stock market volatility leading to higher risks of a fundamental change in the political and economic system - is unlikely to be a large problem. Of greater concern is potential omitted variable bias. Recessions are known to be systematically associated with higher stockmarket volatility (Schwert 1990, Schwert 1989b). If generally poor economic performance led simulateously to both greater worker militancy, associated with a higher perceived risk of political turmoil, and to higher stock volatility, the documented impact of our indicators of civic unrest might be spurious. There is also the possibility that higher volatility of output results in unemployment, leading to a rise in economic misery and (perceived) threats to the survival of the capitalist system.

To control for the differential effects of recessions, I include the percentage change in real per capita income in the regressions. Since the effect might well be non-linear, I also experiment with the square of the 
annual growth rate. Both variables clearly play a role, but the significance of risk-of-revolution variable and the chaos indicator is not undermined.

\section{Table XII}

Stock Price Volatility and Macroeconomic Performance

The table reports results for the regression

$\sigma_{i t}=\alpha_{1}+\beta_{1} X_{i t}+\beta_{2} P_{i t}+\varepsilon$

Estimation technique is seemingly unrelated regressions (SUR). T-statistics (based on White heteroscedasticity-consistent covariances) in parentheses. For data sources, cf. Data Appendix. The sample contains all countries. ${ }^{*}, *$ indicate significance at the 10 and $5 \%$ level, respectively.

\begin{tabular}{|c|c|c|c|c|c|c|c|c|}
\hline & 1 & 2 & 3 & 4 & 5 & 6 & 7 & 8 \\
\hline CHAOS & $\begin{array}{c}0.002^{\star \star} \\
(6.2)\end{array}$ & & & & $\begin{array}{c}0.004^{\star \star} \\
(2.7)\end{array}$ & & $\begin{array}{c}0.0013^{* \star} \\
(4.99)\end{array}$ & \\
\hline RISK & & $\begin{array}{c}0.065^{* *} \\
(5.11)\end{array}$ & & & & $\begin{array}{c}0.18^{\star *} \\
(2.5)\end{array}$ & & $\begin{array}{c}0.036^{*} \\
(2.2)\end{array}$ \\
\hline RISK2 & & & $\begin{array}{c}0.05^{\star \star} \\
(4.4)\end{array}$ & & & & & \\
\hline CRISK & & & & $\begin{array}{c}0.027^{* *} \\
(2.4)\end{array}$ & & & & \\
\hline GROWTH & $\begin{array}{c}-0.028 \\
(1.1)\end{array}$ & $\begin{array}{c}-0.038^{*} \\
(1.68)\end{array}$ & $\begin{array}{c}-0.04^{*} \\
(1.9)\end{array}$ & $\begin{array}{c}-0.043^{*} \\
(1.7)\end{array}$ & $\begin{array}{c}0.08 \\
(0.07)\end{array}$ & $\begin{array}{l}0.11 \\
(1.0)\end{array}$ & $\begin{array}{c}-0.089^{* *} \\
(2.6)\end{array}$ & $\begin{array}{c}-0.098^{* *} \\
(3.0)\end{array}$ \\
\hline GROWTH $^{2}$ & & & & & & & $\begin{array}{c}0.0013^{* *} \\
(3.6)\end{array}$ & $\begin{array}{c}1.99^{* *} \\
(5.4)\end{array}$ \\
\hline Fixed effects & NO & NO & NO & NO & NO & NO & NO & NO \\
\hline $\operatorname{adj} . R^{2}$ & 0.054 & 0.026 & 0.011 & 0.016 & 0.007 & 0.008 & 0.19 & 0.17 \\
\hline $\mathrm{N}$ & 196 & 196 & 196 & 196 & 195 & 196 & 196 & 196 \\
\hline
\end{tabular}

\section{Summary and Conclusions}

Did fear about social unrest and the danger of a violent challenge to the economic status quo contribute to share price volatility in the interwar period? I find strong evidence in favor of such a link. Anti-government strikes and demonstrations as well as riots appear to have made equity investors in a set of 10 developed countries significantly more jittery. These results help to explain why some countries saw extraordinarily wide swings in share prices in the course of a single year - more than 40 percent in Germany in the early 1920s, and approximately half this level in the US in 1932. This provides direct evidence in favor of the Schwert/Merton hypothesis - the "volatility puzzle" during the Great Depression can partly be resolved if we account for the danger of a political discontinuity, brought on by the social dislocation of the slump. Not only are dangers to the capitalist system in the US an explanatory factor during the Slump, they are also important in understanding the extreme volatility seen in some European stock markets during the 1920s and 1930s. It is therefore no accident that the "heyday of 
American communism" (Klehr 1984) also saw violent swings in share prices; similar forces were operative in countries where the establishment had reasons to worry about the ability to beat back revolutionary movements that tried to profit from the depression. As Schlesinger observed in the case of the United States: "Now depression was offering radicalism its long awated chance." (Schlesinger 1957, 206).

This argument can be reinforced by deriving a measure of the risk of revolution, based on the observed correlations between social unrest, political violence, and the revolutions that do occur in our sample period. This "threat variable" is a highly significant predictor of higher stock price volatility, lending further credence to the hypothesis that investors feared a possible repeat of the Russian Revolution in other countries. The impact of such an event is, as Schwert (1989b), has argued, similar to a "Peso problem" - not easily measured ex post, but clearly relevant to the decision-making of economic agents at the time. I also find that weaker democracies, as indicated by greater fractionalization and more frequent elections, were more prone to experience wild swings in equity prices.

I do not argue that political violence, worker militancy and civic unrest were exogenous to changes in economic conditions. As the political and social history of the countries in our samples makes abundantly clear, the strength of radical movements ebbed and flowed with the economic fortunes of their countries (Stögbauer 2001, Falter 1991). Many of the countries that experienced particularly severe economic shocks saw considerable upheaval. The extent to which political collapse followed economic misery varied considerably. While Germany and Italy became dictatorships during our period, the US democratic system survived an economic crisis that was as severe as Germany's. As recent work by Bittlingmayer (1998) has shown, uncertainty in general may well have aggravated the decline in industrial activity that was in part behind the upsurge in political violence and worker militancy. What our results do show is that in those countries where economic shocks of the early $1920 \mathrm{~s}$ and, again, in the early $1930 \mathrm{~s}$, led to greater political instability or the risk thereof, stock prices began to swing wildly. While political chaos contributed to extreme stock price volatility, my results also document that a part of the "volatility puzzle" still remains - the models developed in the empirical section are not able to fully predict the variability actually observed.

These findings suggest a clear agenda for future research. Recent work on US share returns that decomposes the variability of aggregate indices into the volatility of individual shares and the degree of "synchronicity" (Campbell et al. 2001, Morck, Yeung and Yu 2000) should be replicated for other countries during the interwar period. The Schwert/Merton hypothesis would receive further confirmation if panel evidence confirmed a systematic association between synchronicity on the one hand, and indicators of social unrest and political instability on the other. An alternative route for future 
research would be to construct indices of political risk at higher frequencies, using some of the techniques based on news reports that have been used in an attempt to explain variability in post-war data sets (Cutler, Poterba and Summers 1989). With these, fully specified GARCH-models could be estimated that would allow a more detailed modelling of the transmission process from political uncertainty to stock price volatility. 


\section{Data Appendix}

The stock price indices are from Global Financial Data (at http://www.globalfindata.com). The individual series used are given in Table XIII.

Table XIII: Data sources - Stock Indices and CPI

\begin{tabular}{|c|c|c|c|}
\hline & Stock index & file & $\begin{array}{l}\text { file for cpi price } \\
\text { index }\end{array}$ \\
\hline UK & $\begin{array}{l}\text { UK-FTSE All } \\
\text { Share Index }\end{array}$ & FTSAV.csv & CPGBRM.csv \\
\hline Belgium & $\begin{array}{l}\text { CBB Spot Price } \\
\text { Index }\end{array}$ & _BSPTD.csv & CPBELM.csV \\
\hline USA & S\&P-500 & _SPXD.csv & CPUSAM.csv \\
\hline France & SBF-250 & _SBF250D.csv & CPFRAM.csv \\
\hline Italy & BCI General & BCIID.csv & CPITAM.csv \\
\hline Netherlands & CBS All-Share & _CBSAD.csv & CPNLDM.csv \\
\hline Sweden & $\begin{array}{l}\text { Affarsvarlden } \\
\text { General }\end{array}$ & _SWAVD.csv & CPSWEM.csv \\
\hline Norway & OBX-25 & _OBXD.csv & CPNORM.csv \\
\hline Switzerland & $\begin{array}{l}\text { Switzerland Price } \\
\text { Index }\end{array}$ & SPIXD.csv & CPCHEM.csv \\
\hline
\end{tabular}

The exception is Germany, where the hyperinflation limits data availability. I use the series compiled by Gielen (1992). For the period after 1919, it is based on statistics compiled by the Imperial Statistical Office. His series is now widely accepted as the best available long-run equity index for Germany (Bittlingmayer 1998, Jorion and Goetzmann 1999). The growth rates of GDP per capita are taken from Maddison 1995; GROWTH is calculated as the difference between the natural logarithms of GDP in the preceding year and the current year.

The political variables and indicators of unrest are from Banks (1976). The code numbers and definitions are given in Table XIV. 


\section{Table XIV}

\section{Definition of Political and Social Variables}

The table gives the definitions of the various indicators of political violence, legislative efficiency and social instability used in our study. Source: Banks 1976.

\begin{tabular}{|c|c|c|}
\hline $\begin{array}{l}\text { Variable } \\
\text { name }\end{array}$ & $\begin{array}{l}\text { Variable } \\
\text { number }\end{array}$ & Definition \\
\hline ASS & 91 & $\begin{array}{l}\text { The number of assassinations, defined as any } \\
\text { politically motivated murder or attempted murder } \\
\text { of a high government official or politician. }\end{array}$ \\
\hline STRIKE & 92 & $\begin{array}{l}\text { The number of general strikes, defined as any } \\
\text { strike of } 1,000 \text { or more industrial or service workers } \\
\text { that involves more than one employer and that is } \\
\text { aimed at national government policies or authority. }\end{array}$ \\
\hline GUE & 93 & $\begin{array}{l}\text { The number of acts of guerrilla warfare, defined as } \\
\text { any armed activity, sabotage, or bombings carried } \\
\text { on by independent bands of citizens or irregular } \\
\text { forces and aimed at the overthrow of the present } \\
\text { regime. }\end{array}$ \\
\hline CRISIS & 94 & $\begin{array}{l}\text { The number of major government crises, defined as } \\
\text { any rapidly developing situation that threatens to } \\
\text { bring the downfall of the present regime - excluding } \\
\text { situations of revolt aimed at such overthrow. }\end{array}$ \\
\hline PURGE & 95 & $\begin{array}{l}\text { The number of purges, defined as any systematic } \\
\text { elimination by jailing or execution of political } \\
\text { opposition within the ranks of the regime or the } \\
\text { opposition. }\end{array}$ \\
\hline RIOT & 96 & $\begin{array}{l}\text { The number of riots, defined as any violent } \\
\text { demonstration or clash of more than } 100 \text { citizens } \\
\text { involving the use of physical force. }\end{array}$ \\
\hline REV & 97 & $\begin{array}{l}\text { The number of revolutions, defined as any illegal or } \\
\text { forced change in the top governmental elite, any } \\
\text { attempt at such a change, or any successful or } \\
\text { unsuccessful armed rebellion whose aim is } \\
\text { independence from the central government. }\end{array}$ \\
\hline DEMO & 98 & $\begin{array}{l}\text { The number of anti-government demonstrations, } \\
\text { defined as any peaceful public gathering of at least } \\
100 \text { people for the primary purpose of displaying or } \\
\text { voicing their opposition to government policies or } \\
\text { authority, excluding demonstrations of a distinctly } \\
\text { anti-foreign nature. }\end{array}$ \\
\hline FRAC'TURE & 113 & $\begin{array}{l}\text { Party fractionalization index, based on a formula } \\
\text { proposed by Rae 1968. The index is constructed as } \\
\text { follows: }\end{array}$ \\
\hline
\end{tabular}


PARLRES

$\mathrm{CABCH}$

EXECCH

NELECT 127
$F=1-\sum_{i}^{n}\left(t_{i}\right)^{2}$

where $t$ is the proportion of members associated with the ith party in the lower house of the legislature.

121 Parliamentary responsibility, defined as the degree to which a premier must depend on the support of a majority in the lower house of a legislature in order to remain in office.

Code Definition

0 Irrelevant. Office of premier does not exist.

1 Absent. Office of premier exists, but there is no parliamentary responsibility.

2 Incomplete. The premier is, at least to some extent, constitutionally responsible to the legislature. Effective responsibility is, however, limited.

3 Complete. The premier is constitutionally and effectively dependent upon a legislative majority for continuance in office.

123 Major cabinet changes, defined as the number of times in a year that a new premier is named and/or $50 \%$ of the cabinet posts are occupied by new ministers.

124 The number of times in a year that effective control of the executive power changes hands. Such a change requires that the new executive be independent of his predecessor. a national legislature in a given year. strike+demo+riot 

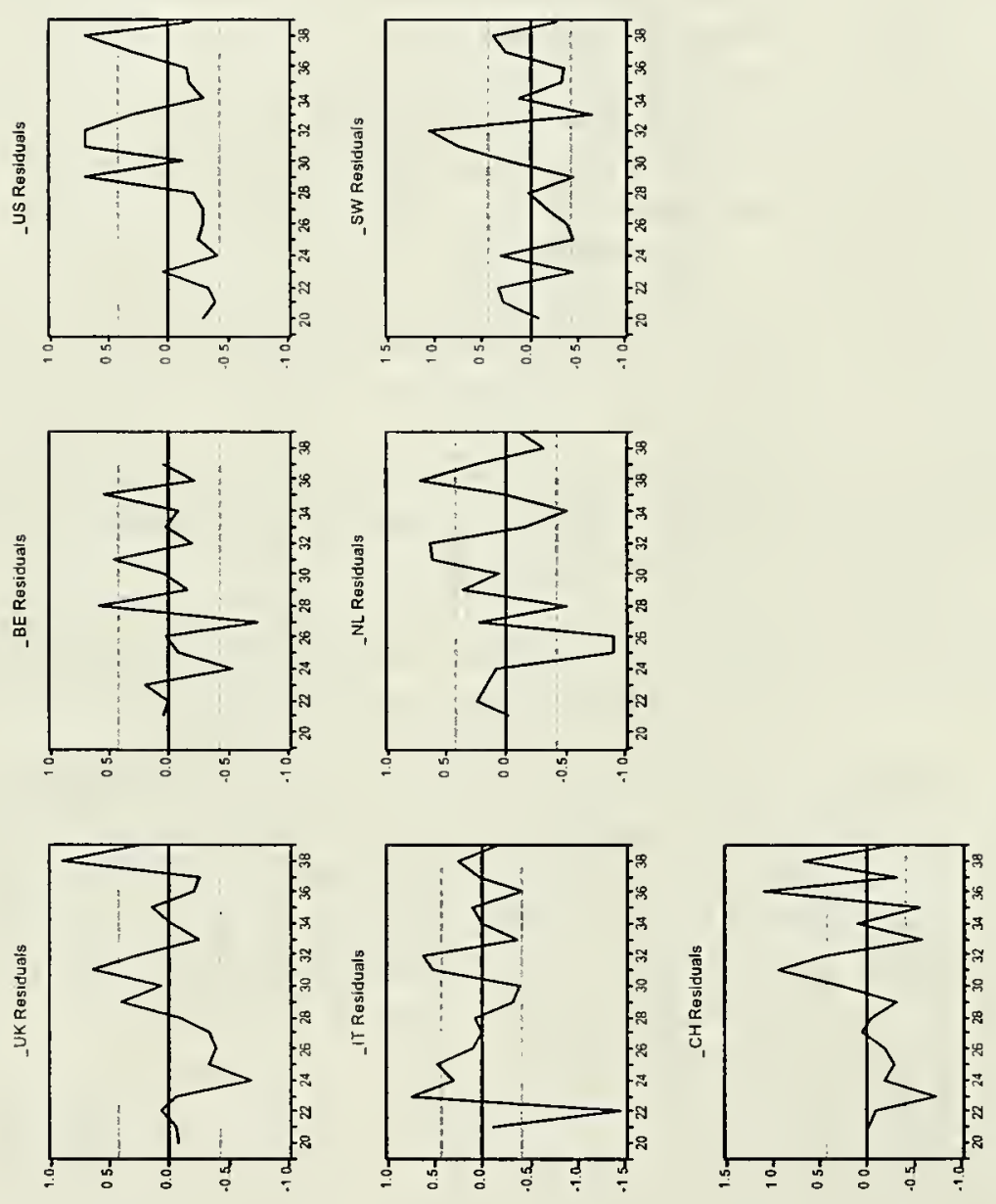

 


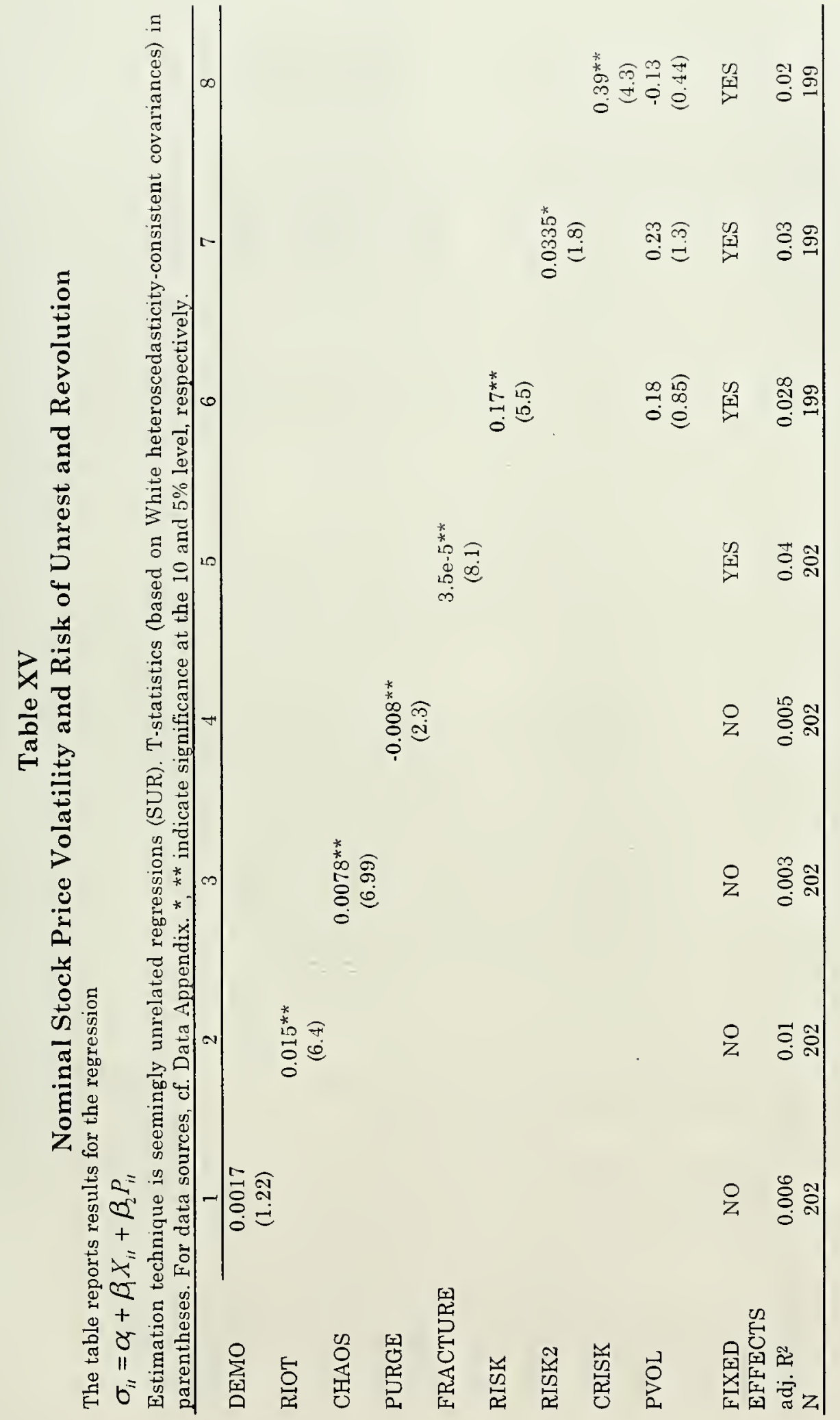




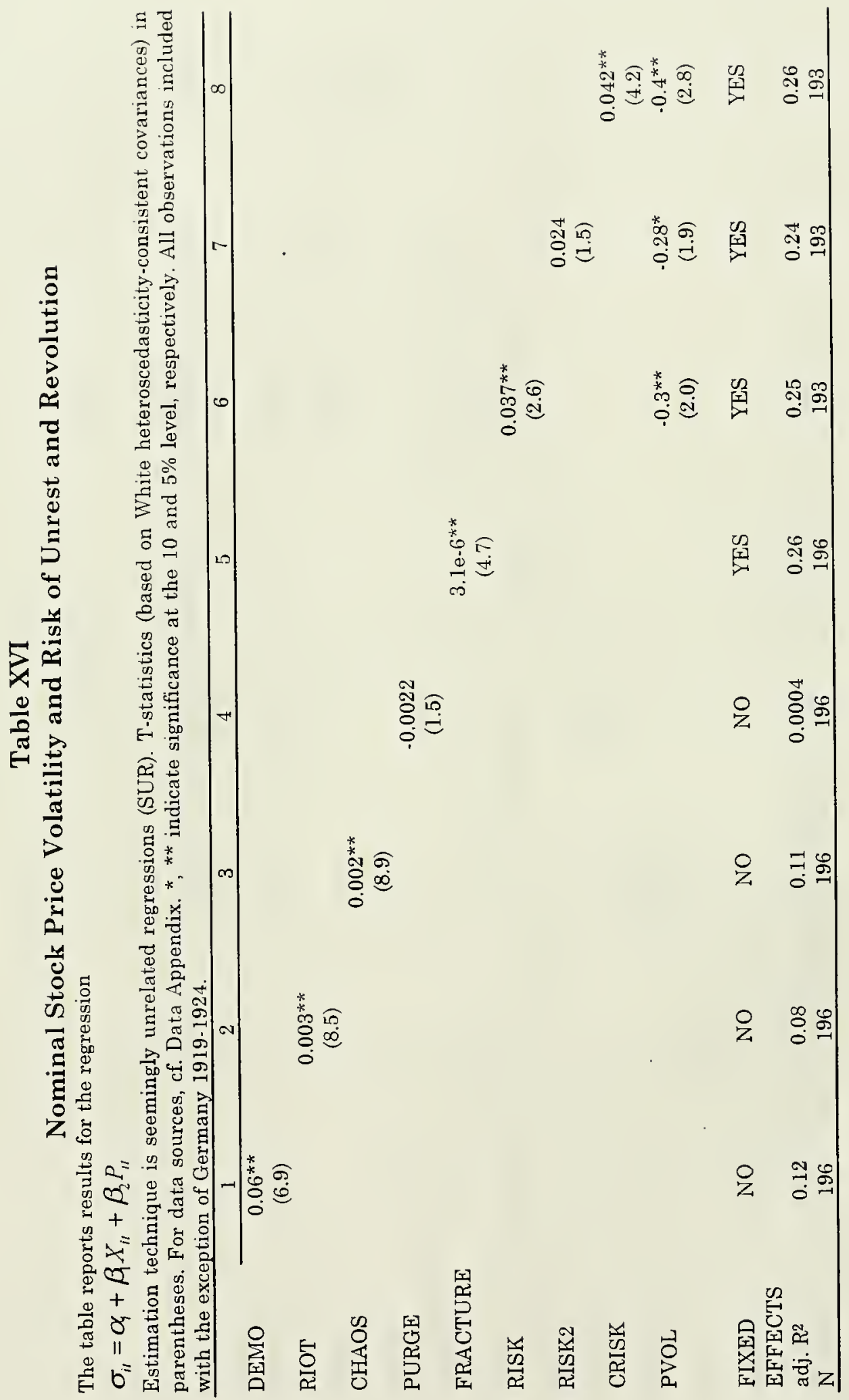


References

Acemoglu, D. and J. A. Robinson (1999). A Theory of Political Transitions. In, Massachusetts Institute of Technology, Department of Economics Working Paper: 99/26: 31.

(2000). "Why Did the West Extend the Franchise? Democracy, Inequality, and Growth in Historical Perspective." Quarterly Journal of Economics 115(4): 1167-99.

Agrawal, A. and C. R. Knoeber (1998). "Managerial Compensation and the Threat of Takeover." Journal of Financial Economics 47(2): 219-39.

Alesina, A. and R. Perotti (1996). "Income Distribution, Political Instability, and Investment." European Economic Review 40(6): 1203-28.

Balderston, 'T. (1993). The Origins and Course of the German Crisis. Berlin, Haude \& Spener.

Banks, A. S. (1976). Cross-National Time Series, 1815-1973. In, Inter-University Consortium for Political and Social Research.

Bekaert, G. and C. R. Harvey (1997). "Emerging Equity Market Volatility." Journal of Financial Economics 43(1): 29-77.

Bittlingmayer, G. (1998). "Output, Stock Volatility, and Political Uncertainty in a Natural Experiment: Germany, 1880-1940." Journal of Finance 53(6): 224357.

Borchardt, K. (1991). Perspectives on Modern German Economic History and Policy. Cambridge; New York, Cambridge University Press.

Campbell, J. Y., et al. (2001). "Have Individual Stocks Become More Volatile? An Empirical Exploration of Idiosyncratic Risk." Journal of Finance 56(1): 1-43.

Campbell, J. Y., A. W. Lo and A. C. MacKinlay (1997). The Econometrics of Financial Markets. Princeton, N.J., Princeton University Press.

Cutler, D. M., J. M. Poterba and L. H. Summers (1989). "What Moves Stock Prices?" Journal of Portfolio Management 15(3): 4-12.

David, A. and P. Veronesi (2001). "Inflation and Earnings Uncertainty and the Volatility of Asset Prices: An Empirical Investigation." unpublished manuscript. Chicago.

DeFronzo, J. (1991). Revolutions and revolutionary movements. Boulder, Westview Press.

Eichengreen, B. and O. Jeanne (1998). "Currency Crisis and Unemployment: Sterling in 1931." Centre for Economic Policy Research, Discussion Paper: 1898.

Eichengreen, B. and J. Sachs (1985). "Exchange Rates and Economic Recovery in the 1930s." Journal of Economic History 45(4): 925-46.

Eichengreen, B. J. (1992). Golden Fetters : The Gold Standard and the Great Depression, 1919-1939. New York, Oxford University Press.

Falter, J. W. (1991). Hitlers Wähler. München, Beck.

Feinstein, C. H., P. Temin and G. Toniolo (1997). The European Economy Between the Wars. Oxford ; New York, Oxford University Press. 
Feldman, G. D. (1993). The Great Disorder: Politics, Economics and Society in the German Hyperinflation, 1914-1924. Oxford, Oxford University Press.

Flanders, A. (1968). "Great Britain". In: Comparative Labor Movements, edited by W. Galenson. New York, Russell \& Russell.

Foner, P. (1988). History of the Labor Movement of the United States. New York, International Publishers.

Galbraith, J. K. (1962). The Great Crash, 1929. New York, Time.

Gasiorowski, M. J. (1995). "Economic Crisis and Political Regime Change: An Event History Analysis." American Political Science Review 89(4): 882-97. ·

Goldstone, J. A. (1991). Revolution and rebellion in the early modern world. Berkeley, University of California Press.

Goldstone, J. A. and R. K. Merton (1986). Revolutions : theoretical, comparative and historical studies. San Diego.

Grossman, H. I. (1999). "Kleptocracy and Revolutions." Oxford Economic Papers 51(2): $267-83$.

Hamilton, J. (1986). "On Testing for Self-fulfilling Speculative Price Bubbles." International Economic Review 27(3): 545-52.

Hamilton, J. and C. Whiteman (1985). "The Observable Implications of Self-fulfilling Expectations." Journal of Monetary Economics 16(3): 353-73.

$\mathrm{Hu}, \mathrm{X}$. and T. D. Willett (2000). "The Variability of Inflation and Real Stock Returns." Applied Financial Econornics 10(6): 655-65.

Jorion, P. and W. N. Goetzmann (1999). "Global Stock Markets in the Twentieth Century." Journal of Finance 54(3): 953-80.

Klehr, H. (1984). The Heyday of American Communism : The Depression Decade. New York, Basic Books.

Kleidon, A. (1986). "Variance Bound Tests and Stock Price Valuation Models." Journal of Political Economy 94: 953-1001.

Lorwin, V. (1968). "France". In: Comparative Labor Movements, edited by W. Galenson. New York, Russell \& Russell.

Maddison, A. (1995). Monitoring the World Economy. Paris, OECD.

Maier, C. S. (1975). Recasting Bourgeois Europe : Stabilization in France, Germany, and Italy in the Decade after World War I. Princeton, N.J., Princeton University Press.

Mei, J. (1999). "Political Risk, Financial Crisis, and Market Volatility." NYU Business Department Working Paper.

Moggridge, D. E. (1972). British Monetary Policy, 1924-1931: The Norman Conquest of \$4.86. Cambridge, UK, Cambridge University Press.

Morck, R., B. Yeung and W. Yu (2000). "The Information Content of Stock Markets: Why Do Emerging Markets Have Synchronous Stock Price Movements?" Journal of Financial Economics 58(1-2): 215-60.

Muller, E. and M. Seligson (1987). "Inequality and Insurrections." American Political Science Review 81: 425-451.

Nolte, E. (1963). Der Faschisınus in seiner Epoche: die Action française, der italienische Faschismus, der Nationalsozialismus. München, R. Piper.

Officer, R. R. (1973). "The Variability of the Market Factor of the New York Stock Exchange." Journal of Business 46(3): 434-53.

Prezworski, A., et al. (1996). "What Makes Democracy Endure." Journal of Democracy 7(7): 39-55. 
Rae, D. (1968). "A Note on the Fractionalization of Some European Party Systems." Comparative Political Studies 1: 413-418.

Schiller, R. (1981). "Do Stock Prices Move too Much to Be Explained by Subsequent Changes in Dividends?" American Economic Review 75: 421-436.

Schlesinger, A. (1957). The Crisis of the Old Order, 1919-1933. Boston, Houghton Mifflin.

Schmidt, R. (2000). Red Scare: FBI and the Origins of Anticommunism in the United States, 1919-1943. Copenhagen, Museum Tusculanum Press University of Copenhagen.

Schwert, G. W. (1989a). "Business Cycles, Financial Crises, and Stock Volatility: Reply." Carnegie-Rochester Conference Series on Public Policy 31(0): 133-37. (1989b). "Why Does Stock Market Volatility Change over Time?" Journal of Finance 44(5): 1115-53.

(1990). "Stock Returns and Real Activity: A Century of Evidence." Journal of Finance 45(4): 1237-57.

Stögbauer, C. (2001). "Measuring the Impact of the Depression on the Radical Vote in the Weimar Republic: A Spatio-temporal Approach." Economic History Working Paper. Munich.

Taft, P. (1958). "Germany". In: Comparative Labor Movements, edited by W. Galenson. New York, Russell \& Russell.

Turner, H. A. (1985). German Big Business and the Rise of Hitler. New York, Oxford University Press.

Winkler, H. A. (1985). Von der Revolution zur Stabilisierung : Arbeiter und Arbeiterbewegung in der Weimarer Republik, 1918 bis 1924. Berlin, J.H.W. Dietz.

Zinn, H. (1999). A People's History of the United States : 1492-Present. New York, NY, HarperCollins Publishers. 
,

$=$

$\therefore i$ ! 

Date Due $3 / 28 /$ os

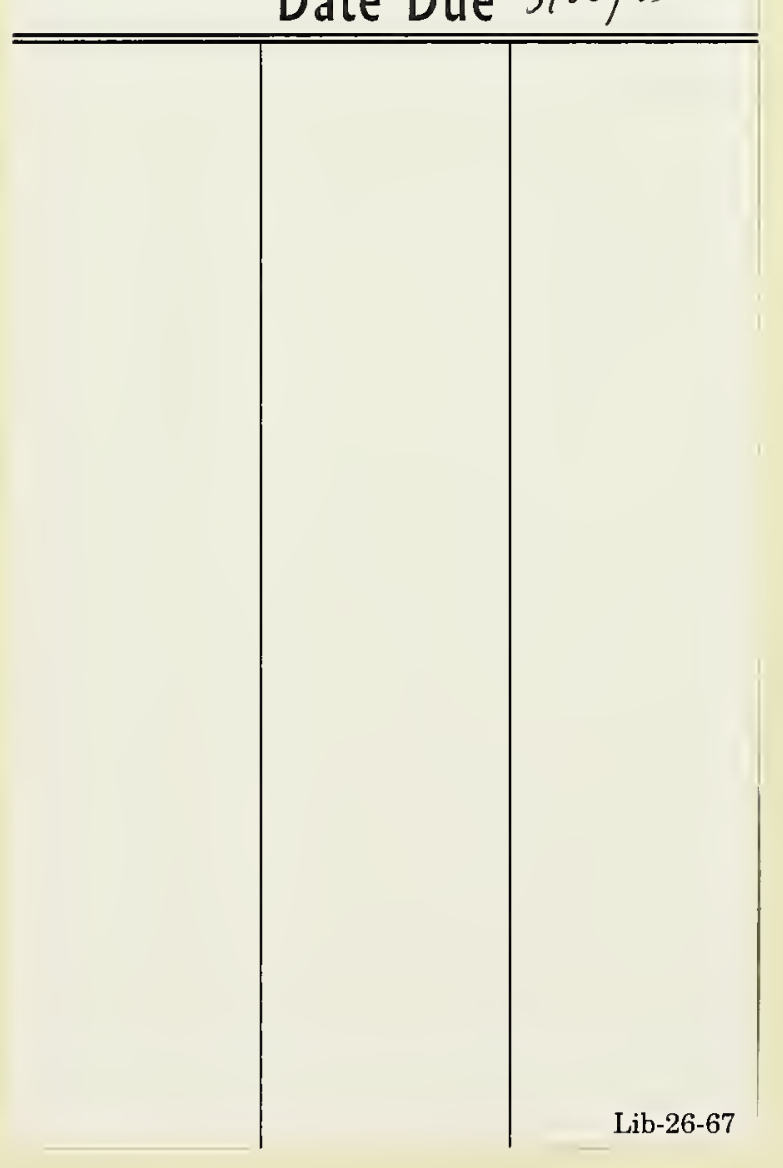




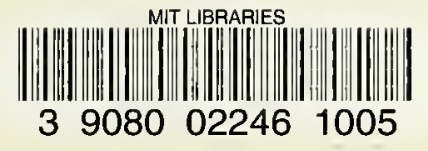


